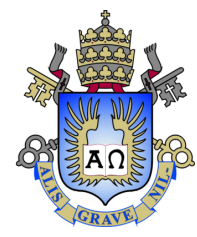

Pompeu Hoffmann Júnior

\title{
Why do Brazilian bank-affiliated mutual funds underperform?
}

Dissertação de Mestrado

Dissertation presented to the Programa de Pós-graduação em Economia da PUC-Rio in partial fulfillment of the requirements for the degree of Mestre em Economia.

Advisor : Prof. Ruy Monteiro Ribeiro Co-advisor: Prof. Walter Novaes Filho 

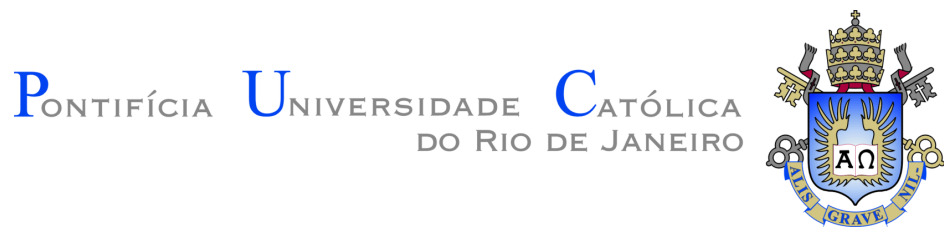

Pompeu Hoffmann Júnior

\section{Why do Brazilian bank-affiliated mutual funds underperform?}

Dissertation presented to the Programa de Pós-graduação em Economia da PUC-Rio in partial fulfillment of the requirements for the degree of Mestre em Economia. Approved by the undersigned Examination Committee.

Prof. Ruy Monteiro Ribeiro

Advisor

Departamento de Economia - PUC-Rio

Prof. Walter Novaes Filho

Co-advisor

Departamento de Economia - PUC-Rio

Prof. Marco Bonomo

Departamento de Economia - Insper

Alexandre Lowenkron

Banco BBM - S/A

Prof. Augusto Cesar Pinheiro da Silva

Vice Dean of the Centro de Ciências Sociais - PUC-Rio

Rio de Janeiro, March the 15th, 2018 
All rights reserved.

\section{Pompeu Hoffmann Júnior}

B.A., Economics, Universidade Federal do Rio Grande do Sul (UFRGS), 2015.

Bibliographic data

Hoffmann Júnior, Pompeu

Why do Brazilian bank-affiliated mutual funds underperform? / Pompeu Hoffmann Júnior; advisor: Ruy Monteiro Ribeiro; co-advisor: Walter Novaes Filho. - Rio de janeiro: PUCRio, Departamento de Economia, 2018.

v., 70 f: il. color. ; $30 \mathrm{~cm}$

Dissertação (mestrado) - Pontifícia Universidade Católica do Rio de Janeiro, Departamento de Economia.

Inclui bibliografia

1. Economia - Teses. 2. Conglomerados Financeiros;. 3. Fundos Mútuos;. 4. Tomade de Risco;. I. Monteiro Ribeiro, Ruy. II. Novaes Filho, Walter. III. Pontifícia Universidade Católica do Rio de Janeiro. Departamento de Economia. IV. Título. 


\section{Acknowledgments}

First of all, I want to thank my parents, Vera and Pompeu, who always supported me and encouraged me to achieve higher goals. Thank you for being these inspirational figures.

I am thankful for all the patience, love and care from Rilari.

I would also like to thank my advisor and co-advisor, Ruy and Walter. Your guidance was essential in order to get this work done. All the knowledge, inside and outside the classroom, you helped me to acquire is priceless, and I will always be thankful for that.

I also appreciate the resourceful conversations I had with Márcio Garcia, Vinícius Carrasco, and Diogo Guillen: you inspired me to become a better economist.

I cannot forget the friends I've made during these two long years and with whom I shared unforgettable moments: all you guys who joined the master with me, you inspired me to become better. Particularly, I am grateful for the meaningful friendships that were forged during these years: Matheus D'amico, Iuri Holanda, Yan Moreira and Henrique Fernandes, you've made it easier.

Long days, short nights. It was worth it. 


\section{Abstract}

Hoffmann Júnior, Pompeu; Monteiro Ribeiro, Ruy (Advisor); Novaes Filho, Walter (Co-Advisor). Why do Brazilian bankaffiliated mutual funds underperform?. Rio de Janeiro, 2018. 70p. Dissertação de mestrado - Departamento de Economia, Pontifícia Universidade Católica do Rio de Janeiro.

This paper investigates financial conglomerates' participation in the Brazilian equity mutual fund industry. Using data from 2002 to 2016, we show that bank-affiliated funds underperform funds managed by stand-alone entities by $1.96 \%-2.30 \%$ per year. Moreover, we find that bank-affiliated fund managers have less incentives to take risk than independent funds'. Consistent with incentives, we show that bank-affiliated funds trade less often, try less to time the market and have portfolios more similar to the market's than independent funds. Finally, we show that differences in risk taking can be associated to $7.68-29.6 \%$ of the performance difference between bank-affiliated and independent funds.

\section{Keywords}

Financial Conglomerates; Mutual Funds; Risk Taking; 


\section{Resumo}

Hoffmann Júnior, Pompeu; Monteiro Ribeiro, Ruy; Novaes Filho, Walter. Por que fundos de ações brasileiros filiados à bancos têm performance diferente de fundos independentes?. Rio de Janeiro, 2018. 70p. Dissertação de Mestrado - Departamento de Economia, Pontifícia Universidade Católica do Rio de Janeiro.

Esse artigo investiga a participação de fundos filiados a conglomerados financeiros na indústria brasileira. Usando dados de 2002 a 2016, mostramos que fundos filiados a bancos apresentam retornos, entre $1.96 \%-2.30 \%$ ao ano, inferior a fundos independentes. Além disso, mostramos que gestores de fundos filiados a bancos têm menos incentivos a tomar risco no mercado do que gestores de fundos independentes. Consistente com os incentivos enfrentados, mostramos que fundos filiados a bancos mudam menos de posição, tentam menos antecipar movimentos de mercado e têm portfólios mais parecidos com o mercado do que fundos independentes. Finalmente, mostramos que as diferenças na tomada de risco pode estar associada a $7.68 \%-29.6 \%$ da diferença de performance entre fundos filiados à bancos e independentes.

\section{Palavras-chave}

Conglomerados Financeiros; Fundos Mútuos; Tomade de Risco; 


\section{Table of contents}

1 Introduction $\quad 10$

2 Data 14

3 Performance of Bank-Affiliated and Independent Equity Mutual Funds 17

$\begin{array}{lll}3.1 & \text { Univariate Portfolio Analysis } & 17\end{array}$

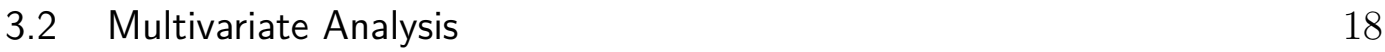

4 Flow-Performance Relationship and Flow Volatility 21

4.1 Empirical Evidence 21

4.2 Robustness Check 24

4.3 Flow-Performance and Fund Family Structure 26

$5 \quad$ Flows' Empirical Findings and Risk Taking Implications 30

5.1 Mutual Funds Risk Taking $\quad 30$

$\begin{array}{lll}5.1 .1 & \text { Heterogeneous Risk Taking } & 30\end{array}$

5.1.2 Heterogeneous Portfolio Risk Shifting 31

5.2 Risk Taking and Mutual Fund Returns 32

5.2.1 Mutual Fund Performance and Active Risk 32

5.2.2 Mutual Fund's Return Volatility and Active Risk 34

6 Conclusion $\quad 35$

$\begin{array}{ll}\text { Bibliography } & 36\end{array}$

$\begin{array}{llr}7 & \text { Tables } & 39\end{array}$

$\begin{array}{lll}8 & \text { Figures } & 56\end{array}$

$\begin{array}{ll}\text { A Appendix } & 58\end{array}$ 


\section{List of figures}

Figure 8.1 Flows and Relative Performance of Bank-Affiliated and Independent Funds

Figure 8.2 Number of Mutual Funds Sold by Fund Families 57

Figure 8.3 Fund's Returns Volatility and Active Share 57 


\section{List of tables}

Table 7.1 Summary Table and Funds' Characteristics Means by Group 39

Table 7.2 Performance of Bank-Affiliated and Independent Equity

Funds Portfolios 40

Table 7.3 Monthly Panel Regressions of Fund Performance 41

Table 7.4 Panel Regressions of Fund Family Performance 42

Table 7.5 Unconditional Flow Volatility Among Independent and Bank-Affiliated Funds

Table 7.6 Heterogeneous Flow-Performance Relationship 44

Table 7.7 Heterogeneous Flow-Performance Relationship in Subsamples

Table 7.8 Heterogeneous Flow-Performance Relationship Using Different Flow Measures

Table 7.9 Fund Families Applications and Redemptions 47

Table 7.10 Flow-performance Relationship Within the Family 48

Table 7.11 Fund Families Applications and Redemptions by Investor Category

Table 7.12 Unconditional Differences in Risk Taking by Equity Mutual Funds

Table 7.13 Brazilian Equity Mutual Funds' Tournament Behavior 51

Table 7.14 Funds' Performance and Active Share $\quad 52$

Table 7.15 Active Share and Fund's Performance 53

Table 7.16 Active Share Deciles and Mutual Funds' Performance 54

Table 7.17 Active Share and Probability of Underperformance 55

Table A.1 Brazilian Mutual Fund Industry Evolution Over 2002-2016 58

Table A.2 Performance of Bank-Affiliated and Independent Equity Mutual Funds Portfolios $\quad 59$

Table A.3 Panel Regressions of Fund Family Performance 60

Table A.4 Panel Regressions of Fund Performance using Subsamples 61

Table A.5 Heterogeneous Flow-Performance Relationship Using Quarterly Data

Table A.6 Flow-Performance Relationship and Sensitivity Interaction With Other Variables

Table A.7 Flow-Performance Relationship of Retail and Non-Retail Investors

Table A.8 Conditional Differences in Risk Taking by Equity Mutual Funds

Table A.9 Brazilian Equity Mutual Funds' Tournament Behavior $\quad 66$

Table A.10 Fund's Return Volatility and Active Share 67

Table A.11 Active Share and Risk-Adjusted Returns 68

Table A.12 Active Share Deciles and Mutual Funds' Performance $\quad 69$

Table A.13 Variable Definitions 70 


\section{Introduction}

Mutual funds are widespread around the world as vehicles for investments in stocks, fixed income assets and financial derivatives. In the end of 2016, managers of 9,500 mutual funds in the U.S. invested over US\$ 16.3 trillion dollars. In Brazil, the fund industry has quadrupled its size in just ten years, reaching US\$ 1.2 trillion in early 2017.

Given the importance of the mutual fund industry, it is not surprising that an extensive literature in Finance has documented different styles of funds - value, growth, momentum, etc - relating them to expected returns and risk characteristics. Notwithstanding, little is yet known about what it takes for a group of financial entrepreneurs to offer to market participants a fund with a momentum style instead of, say, a value one. The common wisdom in the Finance literature is that funds choose styles according to the expertise of the managers they hire, and, in a competitive market for fund managers, any financial entrepreneur can choose any stile for its fund; it just takes to hire the right professional and provide them the right compensation scheme.

And yet, there is evidence that funds affiliated to financial conglomerates are associated with lower expected returns ((1), (2)) and are less risky (3). What explains this pattern? Is it driven by banks' comparative advantage in attracting conservative customers? Or are banks poorly positioned to cater to sophisticated investors? Shedding some light on these question is the main goal of this paper.

I build on the seminal work of (4) to link banks to a family of funds that, from the investors' viewpoint, are easily interchangeable. In a nutshell, banks typically provide loans to a diverse pool of customers and firms, ensuring aggregate returns with low volatility. (4) demonstrates that this diversification strategy lowers delegated costs that might entail a hurdle for the development of the banking industry.

As it turns out, this broad clientèle base suggests a wide range of investment preferences that, in turn, is a driving force for banks to offer a diversified family of funds. Bank affiliated funds, therefore, have comparative advantages in responding to customers eager to change fund styles to minor shocks in beliefs and market signs. In these funds, flows and returns are strongly 
correlated. Under the compensation schemes typically in place in the fund industry, I shall argue that the strong correlation between flows and returns implies less convex payoffs, generating incentives for less active managing styles, less risk and lower expected returns. The pattern observed by (1), (2)) and (3) thus obtains.

To test the link between returns and flows in funds, we use Brazilian equity mutual fund data from 2002 to 2016. The main advantage of using Brazil's data is its monthly frequency, which allows us to explore short-term dynamics that the international literature is not able to, given that only quarterly/semi-annual data is available worldwide. Besides, our data possesses funds' inflows and redemptions, which is also not available outside Brazil. It enables us to infer about intra-family flows dynamics, which has not been yet explored in the literature, and to cross-check our findings by using different flow measures.

From 2002 to 2016, Brazilian equity mutual fund industry more than quadrupled its size, in part due to new entrants from stand-alone entities. Nevertheless the increased competition, bank-affiliated funds maintained an important role in the industry: on average, $47 \%$ of industry's total net assets were managed by bank-affiliated mutual funds. Given that financial conglomerate funds play an important role in the Brazilian industry, we show in this paper that there are important differences between bank-affiliated equity mutual funds and those managed by stand-alone entities.

First, we show that bank-affiliated funds underperform independent funds by 1.96-2.30\% per year, which is not explained by other fund's features, such as size or age. Moreover, this return difference, observed among all traditional performance measures, is not driven by fees and it is not restricted to subsamples. As an potential explanation, we conjecture that this performance difference may be related to the different incentives bank-affiliated and independent fund managers face.

Second, as bank-affiliated fund families contain a higher number of funds than independent ones, we show that bank-affiliated clients permute products more intensively following bad performance than clients from stand-alone entities. By itself, this result is consistent with differences in search costs and in the number of investment alternatives. On the other hand, it affects fund managers' incentives, as bank-affiliated fund managers face a less convex flowperformance relationship than independent funds'. In other words, given that a considerable portion of mutual fund managers' compensation comes from the management fees charged on assets under management, the flow-performance relationship affect risk taking incentives and, consequently performance, as 
suggested by (5). Therefore, our results suggest that the bank-affiliated fund managers have less incentives to take risk than independent ones, which is consistent with the observed performance difference. Also, we present evidence that fund flows are more volatile to bank-affiliated funds than to independent funds, which indicate that the former may enjoy less room for maneuver to take risk than the latter, as proposed by (6).

Finally, consistent with our performance and flows results, we find that bank-affiliated funds take less risk than independent funds: they trade less often, try less to time the market and tilt more their portfolios towards liquid stocks. Besides, bank-affiliated fund managers engage less intensively in mutual fund tournaments than independent ones. More interesting yet, although claiming to be active investors, bank-affiliated funds behave as closet indexers: about $36 \%$ of a given bank-affiliated fund's portfolio do not differ from the Ibovespa index portfolio. On the other hand, independent funds do take active risk by differing their portfolios from the Ibovespa index portfolio by an amount significantly greater than bank-affiliated funds. The most part of bank-affiliated (independent) funds have a low (high) level of Active Share, and therefore behave as closet indexers (active investors).

In line with the international literature about mutual fund performance evaluation $((7)$, (8)), we show that fund performance is increasing in the amount of active risk taken, which is consistent with our performance evidence. From differences in Active Share between bank-affiliated and independent funds, we infer that the smaller amount of risk taken by bank-affiliated funds can account for $7.68-29.6 \%$ of their underperformance relative to independent funds.

Also, we provide evidence that return volatility and the probability of bank-affiliated funds experiencing large outflows is increasing in Active Share, which may explain their reluctance to take active risk. Hence, we conclude that a considerable portion of bank-affiliated underperformance relative to independent funds can be related to their differences in risk taking and their incentives to do so.

This paper belongs to a growing literature which explores how products and services offered by stand-alone entities and financial conglomerates differ. Similar to our paper, (9) investigates whether Brazilian equity bank-affiliated mutual funds enjoy market power. We differentiate our paper by using a larger data set, comprising all the period from 2002 to 2016, which includes their sample period (2002-2006). Also, they study bank-affiliation to the five biggest Brazilian banks, while we define as bank-affiliated the mutual fund which is affiliated to a bank, whatever its size. Furthermore, we analyze 
heterogeneities in risk taking, flow-performance relationship and fund family structure, whereas they just compare differences in performance and fees charged.

This paper is also related to (2), (1) and (10), which provide mixed evidence about U.S bank-affiliated mutual funds underperformance relative to independent funds. Whereas these papers explore the performance difference between these two groups of funds in the context of conflicts of interest, we analyze how much of it can be related to differences in risk taking. By providing an additional mechanism (e.g, heterogeneity in the flow-performance relationship), we show that funding differences may be as important as information flows and/or distorted incentives in order to explain the performance difference between bank-affiliated and independent funds.

Most recently, (3) analyzed how financial conglomerate affiliation by U.S hedge funds is related to their flow-performance relationship and risk taking. This paper differs by investigating other fund family aspects differences, such as intra-family flow dynamics. Moreover, by investigating a different asset class (equity mutual funds) and a country with a lower level of financial system development (emerging market economy), we obtain opposite results and provide new insights to the literature. Hence, our findings suggest that the results obtained from U.S data may not be taken for granted, in the sense that extending them to other countries may not provide an accurate picture of the local mutual or hedge fund industry.

This article is organized as follows: Section 2 presents the data; Section 3 presents evidence about bank-affiliated mutual funds underperformance relative to independent ones; Section 4 presents flow-performance relationship estimates and construct hypotheses about heterogeneities in risk taking; Section 5 provides risk taking evidence and explains how it is related to the results presented in Section 3 and 4; in Section 6 we conclude. 


\section{2 \\ Data}

We obtained monthly Brazilian mutual fund data from CVM through Quantum Finance platform, from January 2002 to December 2016. Besides funds' characteristics, such as returns and fees, we also obtained monthly portfolio disclosure for each fund, which is used to compute our main risk measure, the Active Share.

The main advantage of using Brazil's data is its monthly frequency, which allows us to explore short-term dynamics that the international literature is not able to, given that only quarterly/semi-annual data is available worldwide. Besides, our data possesses funds' applications and redemptions, which is also not available outside Brazil. It enables us to infer about intra-family flows dynamics, which has not been yet explored in the literature, and to crosscheck our findings by using different flow measures.

In order to ensure that our sample was composed of active equity funds, we excluded Index funds and Privatization funds. We exclude index funds because we are interested in active funds, whose sample potentially have more heterogeneity in regard to performance and fees charged. The reason we exclude Privatization funds is that most of these funds are not true active, in the sense that their portfolios do not change along time and they are composed of only one stock (from the privatized company which composes their names).

We also followed the usual approach for dealing with different client classes of the same fund, known in Brazil as FICs ("Fundos de Investimento em Cotas"). Intuitively, FICs are just vehicles to direct investment flows towards the fund (portfolio) which generates the returns, being the difference between them just the fees charged and/or period to redemption. Hence, in order to not include twice (or more times) the same fund in our sample, we decided to exclude all the FICS from the same fund except one of them, whose features are defined as a total net assets weighted average of the characteristics among the FICS.

The final sample is composed of 1195 mutual funds (461 bank-affiliated funds and 734 independent funds) with 93.710 observations (40.075 from bankaffiliated funds and 53.635 from independent funds). ${ }^{1}$

\footnotetext{
${ }^{1}$ We show the number and the total net assets under management of all funds in the
} 
Table 7.1 presents sample means for funds' characteristics. It is clear that differences between bank-affiliated and independent funds naturally emerge: bank-affiliated funds appear to charge smaller fees, are older and belong to larger families. On the other hand, bank-affiliated and independent equity mutual funds do not appear to be different in terms of size, measured by total net assets under management. As these funds appear to be different in important aspects, we use these variables as covariates in our regression analyses.

As we also shed light into fund family's structure, it is important to define what a fund family is. Following the literature $((11),(12))$, we define fund family as the entity responsible for the fund management. As an example, Bradesco fund family in a given month corresponds to the unit involving all funds managed by Bradesco in that month. In order to calculate a fund family's characteristic, we compute the equally-weighted average of that characteristic using funds belonging to the family in a given month. ${ }^{2}$

Following the recent mutual funds' literature, we measure risk using three popular statistics: Tracking Error, Turnover Ratio, and Active Share. For each fund, we calculate its tracking error $(\beta=1)$ as the 12-month rolling standard deviation of the difference between its gross return and Ibovespa index return. On the other hand, when we specify that $\beta$ was estimated, we follow the same methodology but using the difference between fund's gross return and $\hat{\beta}$ times Ibovespa index return. That is,

$$
\text { Tracking Error }{ }_{i, t}=\text { Standard Deviation }\left(\mathrm{R}_{i, t}-\hat{\beta} \mathrm{R}_{M, t}\right)
$$

, where we estimate fund's beta using the whole returns' time series, for each fund.

We also use fund's monthly turnover ratio which is computed from monthly portfolio disclosure, as in (13). We take the minimum of purchases and sells in a given month, and divide it by fund's Total Net Assets at the end of that month. Hence,

$$
\text { Turnover }_{i, t}=\frac{\operatorname{Min}\left(\text { Purchases }_{i, t}, \text { Sells }_{i, t}\right)}{\operatorname{TNA}_{i, t}}
$$

Finally, from disclosure portfolio data we also computed fund's Active Share (7). Intuitively, it measures how different is the fund's portfolio from its benchmark's. Active Share is defined as sample for the end of each year in Table A.1 in Appendix.

${ }^{2}$ We also present our results using the TNA-weighted average. They are invariant. 


$$
\operatorname{Active~Share~}_{i, t}=1-\sum_{j=1}^{N_{i, t}} \operatorname{Min}\left(\mathrm{w}_{i, t}^{j}, \mathrm{w}_{\text {benchmark }_{i}, t}^{j}\right) I\left[\mathrm{w}_{i, t}^{j}>0\right]
$$

, where $\mathrm{N}_{i, t}$ is the number of stocks in fund's i portfolio at month $\mathrm{t}$; $\mathrm{w}_{i, t}^{j}$ is stock j's weight in fund i's portfolio; $\mathrm{w}_{\text {benchmark,t }}^{j}$ is stock j's weight in fund i's benchmark portfolio ; and $\mathrm{I}($.$) is an indicator function. It varies from 0$ (perfect indexer) to 1 (total active management), if there are no short positions. It is common in the literature to label a fund as closet indexer if its active share is below 0.6. In order to compute it, we assume that each fund benchmark is the Ibovespa index. 


\section{3 \\ Performance of Bank-Affiliated and Independent Equity Mu- tual Funds}

In this section we investigate whether there exists a performance difference between Brazilian bank-affiliated and independent equity mutual funds. Notice that depending on the priori hypothesis, we can expect bank-affiliated mutual funds to either underperform or overperform independent funds. If it is believed that bank-affiliated funds have more knowledge about the companies they invest, through information gathered in other bank divisions, then we may expect these funds to present better performance than independent funds.

On the other hand, if we consider that bank-affiliated funds face more bureaucratic issues or operational difficulties due to scale, such as stricter risk management, then it might be that their allocation process may not be as efficient as that of independent funds. In this case, we would expect independent funds to overperform bank-affiliated funds. Hence, it is to be empirically determined whether there exists a performance wedge or not, between bank-affiliated funds and funds managed by stand-alone entities.

\section{1 \\ Univariate Portfolio Analysis}

To examine whether bank-affiliated funds overperform or underperform independent ones, we first compare their returns using a portfolio approach. Specifically, each month we divide mutual funds into two groups: bankaffiliated and independent. Then, within each group, we compute its portfolio return as the TNA-weighted average return of its participants, every month. ${ }^{1}$

In order to evaluate their performance, we use the CAPM 1-factor model, the Fama and French 3-factor model (14) and the Carhart 4-factor model (15), as well as its return in excess of the Ibovespa index return. Specifically, for each portfolio we measure its risk-adjusted return using the estimated alphas from the following models:

${ }^{1}$ The results are robust to the weighting method used to construct the portfolio returns. Table A.2 in Appendix presents the results using equally weighting to compute portfolios' returns. 


$$
\begin{aligned}
& \mathrm{R}_{i, t}-\mathrm{R}_{\text {Ibovespa }, t}=\alpha_{i}+\beta_{1, i} \mathrm{RMRF}_{t}+\epsilon_{i, t} \\
& \mathrm{R}_{i, t}-\mathrm{R}_{\text {Ibovespa }, t}=\alpha_{i}+\beta_{1, i} \mathrm{RMRF}_{t}+\beta_{2, i} \mathrm{SMB}_{t}+\beta_{3, i} \mathrm{HML}_{t}+\epsilon_{i, t} \\
& \mathrm{R}_{i, t}-\mathrm{R}_{\text {Ibovespa }, t}=\alpha_{i}+\beta_{1, i} \mathrm{RMRF}_{t}+\beta_{2, i} \mathrm{SMB}_{t}+\beta_{3, i} \mathrm{HML}_{t}+\beta_{4, i} \mathrm{MOM}_{t}+\epsilon_{i, t}
\end{aligned}
$$

, where $\mathrm{R}_{i, t}$ and $\mathrm{R}_{\text {Ibovespa, } t}$ are the 1-month portfolio i return and the 1-month Ibovespa index return in month $\mathrm{t}$, respectively, $\mathrm{RMRF}_{t}$ is the 1-month market factor return in excess of the risk-free rate; and $\mathrm{SMB}_{t}, \mathrm{HML}_{t}$, and $\mathrm{MOM}_{t}$ are the 1 -month returns of the three (14) factors and the momentum factor. ${ }^{23}$

We report our sample mean test results in Table 7.2, which contains the average portfolio return in excess of Ibovespa index return and the estimated alphas for each portfolio. The first line of Table 7.2 contains the Ibovespa excess return time series average for each portfolio. It shows that bank-affiliated funds did not deliver positive excess returns at significant levels. In contrast, independent funds portfolio outperformed the Ibovespa index by $0.49 \%$ per month, on average. Morever, the average gross (net) returns difference between independent and bank-affiliated funds is $0.42 \%(0.39 \%)$ per month and it is statistically significant at $1 \%$ significance level.

Also, the results are robust to risk-adjusted return measures: independent funds overperformed bank-affiliated funds by $4.58 \%$ annualy, when we measure performance using Carhart 4-factor model alphas. Moreover, the results are not driven by differences in the fees charged: the performance difference between bank-affiliated and independent funds ranges from 0.39-0.35\% per month, using net returns.

\section{2}

\section{Multivariate Analysis}

We are aware that the results above might be driven by differences between bank-affiliated and independent funds that we were not controlling for, such as funds' size and age. In order to mitigate this potential bias in our estimates, we propose a multivariate regression.

As performance measure, we use the CAPM 1-factor, the 3-factor and the 4-factor alphas, and also the fund's return in excess of Ibovespa index return. Following the literature $((15),(16),(17))$, for each fund we regress its

\footnotetext{
${ }^{2}$ Using the Ibovespa index return instead of the Market factor portfolio return does not change our results. The correlation between Ibovespa index returns and the Market factor returns is 0.97 .

${ }^{3}$ All of these factor returns were obtained through NEFIN website. We thank NEFIN for making the data available to the public.
} 
monthly returns on factors portfolios returns using the previous 36 months of data, every month. We then subtract the expected return from the observed return, hence obtaining the alpha as the sum of the model intercept and the residual.

As control set, we use the traditional variables appointed in the literature as having influence on performance. As suggest by (18), we control for fund's and family's size, both measure by the natural logarithm of their Total Net Assets under management. We also control for age and fees charged, as these features influence funds' funding (19), therefore affecting its risk taking and performance (20). In order to control for autocorrelation in performance, we add the lagged return measure to the specification and the flow in the prior period. We also control for investment activity, by adding the fund's tracking error. $^{4}$

In order to implement our extended multivariate analysis, we run the following regression:

$$
\begin{array}{r}
\mathrm{R}_{i, t}=\gamma \text { Bank }_{i, t}+\beta_{1} \mathrm{R}_{i, t-1}+\beta_{2} \operatorname{LogTNA}_{i, t-1}+\beta_{3} \text { LogFamilyTNA }_{i, t-1}+ \\
\beta_{4} \text { Flow }_{i, t-1}+\beta_{5} \text { Age }_{i, t-1}+\beta_{6} \text { ManagementFee }_{i, t-1}+\beta_{7} \text { PerformanceFee }_{i, t-1}+ \\
\beta_{8} \text { TrackingError }_{i, t-1}+\epsilon_{i, t}
\end{array}
$$

, where $\mathrm{R}_{i, t}$ is a fund $\mathrm{i}$ performance measure at month $\mathrm{t}, \mathrm{Bank}_{i, t}$ is a dummy which is equal to 1 if the fund is affiliated to a bank and 0 otherwise, TrackingError $_{i, t}$ is defined in Appendix and other control variables are defined in Table A.13. Our interest is in the sign and magnitude of parameter $\gamma$, which gives the average monthly performance difference between bank-affiliated and independent funds, that is not explained by other fund's characteristics.

The regression results are reported in Table 7.3. The results indicate that bank-affiliation is associated with lower returns on average, given fund's characteristics and past return. Although the estimated performance wedge between bank-affiliated and independent funds is smaller for the multivariate analysis rather than for the portfolio approach, it continues to be both economically and statistically significant. Depending on the performance measure, it ranges from $1.96 \%(0.163 \times 12)$ to $2.30 \%(0.192 \times 12)$ per year, suggesting that fund's characteristics, besides bank affiliation, do not explain the performance difference between bank-affiliated and independent funds.

${ }^{4}$ We define and describe how we computed the risk measures used in Section 2. The results are robust to using other activeness proxies instead, or adding them in the regression, such as turnover, active share and the fund's return standard deviation. 
One might suspect that our results may be biased because some bankaffiliated funds might have presented a dismal performance during our sample period. In order to show that it is not the case, we run monthly panel regressions on the fund family level. The intuition is that if our results are driven by some fund level observations, then aggregating the data in the fund family unit should lead us to not find a significant performance difference between independent and bank-affiliated fund families. The fund family level regression results are reported in Table 7.4. Across all performance measures, the bank-affiliated dummy coefficient continues to be negative and statistically significant at $1 \%$ level, which reinforces our results. ${ }^{5}$

Further robustness checks are presented in Table A.4. For example, we estimated equation (3-4), separately for subperiods: the performance difference between bank-affiliated and independent funds does not change much and maintains its statistical significance across subsamples. We also estimated it using only months when the Ibovespa index return is negative and when it is positive, and the results do not change. ${ }^{6}$ Also, partitioning the sample based on funds whose size did not change significantly during the sample period, we checked that the results are invariant. ${ }^{7}$ Finally, we conduct the same analysis partitioning the sample based on the management fees charged, which also presented similar results.

Overall, we find robust evidence that Brazilian equity independent funds presented better performance than bank-affiliated funds over the period from 2002 to 2016. Although bank-affiliated funds may obtain better information about companies' prospects, from other bank divisions (information flows), our results suggest that it does not offset the performance advantage that independent funds appear to have.

\footnotetext{
${ }^{5}$ Fund Family's characteristics used in Table 7.4 were computed as the equally weighted average of features from the funds which belonged to the family. Table A.4 in Appendix presents the results using TNA-weighted average instead. The results are invariant to the weighting scheme.

${ }^{6}$ In unreported tables, we also conditioned the regression to months when Ibovespa return was above the 75 th and below the 25 th percentile of its distribution. The results do not change.

${ }^{7}$ Specifically, we partition our sample into three categories: (1) Funds whose size was not bigger than the 25th percentile of TNA December 2016 prices distribution; (2) Funds whose size was between the 25th and the 75th percentile of TNA December 2016 prices distribution; and (3) Funds whose size was above the 75th percentile of TNA December 2016 prices distribution.
} 


\section{Flow-Performance Relationship and Flow Volatility}

\section{1}

\section{Empirical Evidence}

In this section, we shed light into the funds' flow-performance relationship and explain how it relates to their risk taking and, ultimately their performance. We surmise that a heterogeneous flow-performance sensitivity may explain a portion of the estimated performance wedge between bank-affiliated and independent funds.

In particular, we conjecture that bank-affiliated funds face less incentives to take risk, relative to independent funds. Thus, we expect that bankaffiliated funds' flow-performance is less convex than that of independent funds, showing that reward to performance improvement is smaller for those funds. Less incentives to carry risk in their portfolios or to change its risk profile conditionally to prior performance may lead bank-affiliated funds to adopt a more conservative approach than other funds. Thus, as basic asset pricing theory suggests that bearing risk is rewarded with higher returns, the described behavior would be consistent with bank-affiliated funds underperformance relative to independent funds.

Also, as pointed out by (6), funds with more stable funding may earn higher risk-adjusted returns. As these funds enjoy more stable flows, they are able to enjoy a longer investment horizon, therefore benefiting from exposure to arbitrage opportunities that otherwise they wouldn't be able to. Hence, when underperforming its peers, a lower flow-performance sensitivity may be useful to a fund, as it enables the fund to carry forward positions that otherwise it would be forced to exit in order to meet redemptions. Moreover, the literature suggests that funds with more stable flows present better performance than funds whose flows are more volatile ((21), (22)).

As a result of more volatile flows, bank-affiliated funds may take less risk, in order to decrease their chances of presenting awful relative performance and, hence their chances of experiencing outflows. Therefore, bank-affiliated funds may underperform funds that present a more stable funding and whose flows are less volatile. 
In order to verify whether our conjectures about flows are valid, we use monthly data to compute the flow measure proposed by (23), which is defined as:

$$
\text { Flow }_{i, t}=\frac{\mathrm{TNA}_{i, t}-\mathrm{TNA}_{i, t-1} \times\left(1+\mathrm{R}_{i, t}\right)}{\mathrm{TNA}_{i, t-1}}
$$

, where $\mathrm{TNA}_{i, t}$ is the total net assets under management in quarter $\mathrm{t}$ for fund $\mathrm{i}$, and $\mathrm{R}_{i, t}$ is fund i's monthly gross return at quarter $\mathrm{t}$.

As argued above, uncertainty about flows, particularly during periods of underperformance, might curb funds' risk taking. Therefore, we first check whether there is any difference in flow unconditional volatility between bankaffiliated and independent funds. Specifically, for each fund we calculate its monthly flow standard deviation. ${ }^{1}$ Then, within each fund group (bankaffiliated or independent) and investor category (institutional, retail, etc..), we compute the group flow volatility equally-weighted average.

The average flow volatility for the typical fund within each category, as well as its difference across groups, are presented in Table 7.5. As the first line shows, aggregating all the categories lead us to find that the average bankaffiliated fund present, on average, a slightly more volatile flow than the typical independent fund. Moreover, across all investors categories, bank-affiliated funds present more volatile flows than independent funds. Although only statistically significant for Pension funds, our results indicate that independent funds' flows are more stable than those of bank-affiliated funds.

As the previous results suggest that flow volatility is higher for bankaffiliated funds, we proceed to estimate it conditionally to recent performance. Following (23), within each fund classification we computed a monthly percentile rank based on funds' accumulated return over the prior six months, ranging from 0 (poorest performance) to 1 (best performance). ${ }^{2}$ Then, for each decile we compute the average flow in the subsequent month, and finally we take the flow time series average within deciles.

The results are presented in Figure 8.1. It shows that independent funds fit properly what has been documented in the literature: best-performing funds enjoy disproportionately more inflows than worst-performing funds suffer outflows. On the other hand, bank affiliated funds' flows are responsive to either good as well as awful performance. It suggests that bank-affiliated clients chase winners, but also avoid losers with about the same intensity. Although independent funds do not suffer outflows when underperforming its peers,

${ }^{1}$ The results continue to hold if we estimate flow standard deviation from daily data.

${ }^{2}$ Our results are robust to the accumulation period. Along the exercise exposure, we show that our results hold for 3, 6, 9 and 12 months. 
bank-affiliated funds experience significant outflows when they underperform. Hence, bank-affiliated funds may restrict the strategies they adopt in order to decrease their chances of presenting dismal returns and, hence suffering outflows.

Notice that our previous analysis do not control for funds' characteristics, such as age and size, which affect how flows respond to prior performance (19). In order to control for funds' heterogeneities besides bank affiliation, we use a piecewise-linear specification, which allows for different flow-performance sensitivities at different levels of performance. Also, it allows for different sensitivities depending on whether the fund is bank-affiliated or independent.

Using the monthly accumulated return percentile rank, we allow the slopes to differ for the lowest quintile (worst performing funds), the middle three quintiles, and the top quintile. Hence, these slopes indicate the marginal fund flow reaction to performance within each performance ranking region. As is common in the mutual funds flow literature $((23),(24),(3))$, for each fund i month t percentile rank position, we define the following variables which are used to estimate flow-performance sensitivities:

$$
\begin{aligned}
\operatorname{Low}_{i, t} & =\operatorname{Min}\left(0.2, \operatorname{Rank}_{i, t}\right) \\
\operatorname{Mid}_{i, t} & =\operatorname{Min}\left(0.6, \operatorname{Rank}_{i, t}-\operatorname{Low}_{i, t}\right) \\
\operatorname{High}_{i, t} & =\operatorname{Rank}_{i, t}-\left(\operatorname{Low}_{i, t}+\operatorname{Mid}_{i, t}\right)
\end{aligned}
$$

We then regress monthly fund flows on lagged ranking performance and control variables, with robust standard errors clustered by month. ${ }^{3}$ Specifically, we estimate the following equation using OLS:

$$
\begin{array}{r}
\text { Flow }_{i, t}=\beta_{1} \operatorname{Low}_{i, t-1}+\beta_{2} \operatorname{Mid}_{i, t-1}+\beta_{3} \operatorname{High}_{i, t-1}+\beta_{4} \operatorname{Low}_{i, t-1} * \operatorname{Bank}_{i, t-1}+ \\
\beta_{5} \operatorname{Mid}_{i, t-1} * \operatorname{Bank}_{i, t-1}+\beta_{6} \operatorname{High}_{i, t-1} * \operatorname{Bank}_{i, t-1}+\boldsymbol{\theta}^{\prime} \text { Controls }_{i, t-1}+\epsilon_{i, t}
\end{array}
$$

We choose as the performance measure the fund gross return, once it is public available and it is usually displayed when one is comparing mutual funds. Besides, as a first robustness check we use performance rankings based on 3, 6, 9 and 12-month accumulated gross returns, separately.

The regression results are presented in Table 7.6. As Figure 8.1 had sug-

\footnotetext{
${ }^{3}$ Monthly flow data is not easily available worldwide, and therefore the literature is based on quarterly data. Table A.5 in Appendix presents the results using quarterly data, and shows that the results are invariant whether we use monthly data or quarterly data.
} 
gested, Brazilian equity mutual funds' flow-performance relationship presents a convex shape. Using the results based on the accumulated returns during the prior six months ranking, an improvement from the 80th percentile to the 90th percentile in a given month is associated with a subsequent flow of $0.9 \%$. On the other hand, an improvement from the 40th percentile to the 50th percentile is associated with an increased in fund flows of $0.1 \%$ only, which shows an existing convex relationship between performance and subsequent flows.

Although bank-affiliated funds also receive disproportionately more inflows when their returns are outstanding relative to when their performance is about average, these funds experience large flow volatility when presenting awful performance. The interaction between the bank dummy and low performance ranking region shows that bank-affiliated funds have higher flowperformance sensitivity than independent funds. Contrary to independent funds whose flows are not sensitive to returns in the low performance region, a decrease from the 20 th percentile to 10th percentile is associated with subsequent flows of $-5.3 \%$ for bank-affiliated funds.

Moreover, across different performance rankings, bank-affiliated funds presented higher flow-sensitivity in the low performance region, whereas their sensitivities are not different from independent funds' in others performance regions. As a result, bank-affiliated funds' flow-performance relationship have a less convex shape than that of independent funds. ${ }^{4}$

\section{2 \\ Robustness Check}

One might suggest that bank-affiliated funds' sensitivities estimates are driven by other funds' feature besides bank-affiliation. These potential features which are not captured by the explanatory variables may bias our estimated flow-performance sensitivities. In this subsection we show that our findings are not influenced by other funds' characteristics and are robust to alternative flow measures.

As a first robustness check, for several funds' characteristics we compute their sample median and partition the sample into two parts: those observations below the characteristic sample median and those above it. Then, we estimate equation (4-4) using subsamples. ${ }^{5}$

\footnotetext{
${ }^{4}$ The literature $((20),(24))$ measures convexity as the difference between the slope for the top region and the slope for the low region.

${ }^{5}$ We also create a dummy which is equal to 1 if the observation is above median for each feature analyzed, and 0 otherwise. Then, we separately, added this dummy interacting with flow-performance sensitivity to the Equation (4-4), and estimate it using the whole sample. The results do not change, and are presented in Table A.6 in Appendix.
} 
The regression results are presented in Table 7.7. The estimated flowperformance sensitivities still reveal a convex flow-performance relationship, across subsamples. Moreover, we still find a higher flow-performance sensitivity in the low performance region for bank-affiliated funds.

When partitioning the sample based on the minimum initial investment, we find that funds whose minimum initial investment is smaller than the median present a more convex flow-performance relationship. Since funds that require a smaller investment are those, at least intuitively, directed to less sophisticated investors, our results are consistent with the literature (24). Moreover, given that the most part of funds with small minimum initial investment requirement are retail funds, our results corroborate (25) which found that the convex flow-performance relationship is sharper for these funds.

Furthermore, the estimated flow-performance sensitivities are sharper for funds whose age is below the median than for funds whose age is above it. Intuitively, performance is more informative about fund's prospects and its managerial skill for young funds than for older funds, whose track records are longer. Hence, flows to young funds should be more sensitive to performance than flows to older funds (19), as we found.

On the other hand, partitioning the sample based on the management fee, we find that flow-performance sensitivities are sharper for pricier funds. The intuition behind it is that as the fund's cost increases, we expected that investors should pay more attention to its quality (26). Hence, given the increased investor monitoring, fund flows should be more responsive to recent performance, which can be viewed as a proxy for fund's quality.

Alternatively, as we expect that sales effort may be focused on more revenue-generating funds, it is expected that pricier funds' flows present higher sensitivity to performance on the high performance region. It may happen because recent good performance make it easier to sell to investors. This effect is exacerbated for bank-affiliated funds as their sales practices are guided by "monthly product shelf" and more aggressive sales goals, as talking to a practitioner revealed it.

The second robustness test we conduct is based on the flow measure used. Although the literature is built on the flow measure estimative proposed by (23), one might question how informative this measure is about funds "real" flows. Fortunately, our data contains the observed monthly funds' applications and redemptions, which allow us to test if our results are robust to alternative flow measures. To that end, we define Net Applications of fund i at month $t$ as its total applications minus redemptions at that month. Also, we define Net Flow of fund $i$ at month $t$ as the net applications at month $t$ divided by month 
t-1 total net assets under management.

The regression results using the new flow measures are presented in Table 7.8. It shows that our findings are robust to the flow measure used. Moreover, it raises the possibility of bank affiliated funds' flows may be less responsive to outstanding performance than independent funds'. As bankaffiliated funds are less rewarded in terms of flows than independent funds when presenting good performance, they have less incentives to take risk and compete for flows. Hence, the results obtained not just borne out our findings, but also reinforces it by providing an additional evidence that bank-affiliated funds face a less convex flow-performance relationship.

We also investigate if our results are driven by retail funds. In order to investigate that, we estimate equation (4-4) separately for retail and not retail funds. The results are presented in Table A.7 in Appendix and shows that the previous results are observed in both subsamples. Moreover, we observe that flow-performance sensitivities are sharper for retail than for institutional funds, which is consistent with (25).

Overall, we find evidence that bank-affiliated and independent funds face different incentives to take risk. We showed that bank-affiliated fund flows are sensitive to awful performance, while independent fund flows are not. Therefore, bank-affiliated funds' flow-performance relationship is less convex than that faced by independent funds, which suggests that those funds may present less incentives to take risk. Furthermore, we find evidences that bankaffiliated fund flows are more volatile than those of independent funds, which may constrain their ability to take risk, as suggested by (6).

\section{3}

\section{Flow-Performance and Fund Family Structure}

As our results show that bank-affiliated funds' clients are prone to redeem their shares following bad performance, while independent funds' clients are not, an important question that arises is what drives this behavior. Although it is plausible that bank-affiliated funds' clients may be different from those who invest in independent funds, the structure in which a fund is inserted also affects how investors buy and redeem shares (21). Moreover, as we do not have data on individual investors, we cannot test differences among them in order to explain their behavior.

Fortunately, we can test differences in funds' families structures. One potential explanation to why bank-affiliated funds' investors redeem more intensively following underperformance than independent funds' is that they have easier access to more investment alternatives. As shown in Figure 8.2, 
bank-affiliated fund families offer a larger number of mutual funds to invest. Intuitively, it is easier and cheaper to switch funds within the same family than across families, once it avoids the bureaucracy of opening an account in other institution and transferring money to it. Also, bank-affiliated funds often do not charge redemption fees from investors, while independent funds do. Therefore, costly search and access to more products may incite bank-affiliated funds' clients to exchange products more intensively than independent funds'.

One implication of the hypothesis stated above is that bank-affiliated families should experience less outflows, in the sense that outflows from one fund are directed to other funds within the fund family, and not out of it. Hence, if our hypothesis is correct, then we would expect that bank-affiliated families' redemptions are more correlated with applications than those of independent families.

In order to test our hypothesis, every month we sum funds' applications and redemptions on the family level. Since we are interested in how much the fund family's redemptions are associated with its applications, we run the following regression:

$$
\begin{array}{r}
\text { Applications }_{i, t}=\beta_{1} \text { Redemptions }_{i, t}+\beta_{2} \operatorname{LogTNA}_{i, t-1}+\beta_{3} \text { Age }_{i, t-1}+ \\
\beta_{4} \text { ManagementFee }_{i, t-1}+\beta_{5} \text { PerformanceFee }_{i, t-1}+ \\
\beta_{6} \text { GrossReturn }_{i, t-1}+\beta_{7} \text { Applications }_{i, t-1}+\epsilon_{i, t}
\end{array}
$$

, where the dependent variable is the monthly family applications $(\mathrm{R} \$)$ and the control set contains the sum of redemptions experienced by family members at the same month and other fund family characteristics, which are defined in Table A.13.

The regression results are presented in Table 7.9. It shows that bankaffiliated regressions present a $\mathrm{R}^{2}$ which is about $100 \%$ higher than those using independent families data. Therefore, bank-affiliated families' redemptions explain much more of the variation of their applications than do independent families'. Moreover, the results are strikingly different: redemptions of $\mathrm{R} \$ 1.00$ are associated with an increase of $\mathrm{R} \$ 0.11$ in applications to independent families. On the other hand, the same increase of $\mathrm{R} \$ 1.00$ in redemptions is associated with an increase of $\mathrm{R} \$ 0.62$ in applications to bank-affiliated families. It amounts to a difference of $517 \%$ when compared to the increase to independent families.

Overall, the results presented in Table 7.9 suggest that bank-affiliated fund families' redemptions are more associated with applications than independent fund families'. Therefore, it is consistent with a larger number of in- 
vestment alternatives being associated with a higher fraction of funds' clients "swapping" products.

Another consequence of our hypothesis is that performance ranking within the family should matter most to bank-affiliated funds than to independent ones. Given that bank-affiliated funds' investors receive a larger menu of investment alternatives, they may also compare funds within the family when evaluating their investments decisions. Moreover, as these investors tend to move money within the family, and not across families, the best-performing funds within the family should receive large inflows following redemptions from other funds within the family.

As we know that funds' segment performance ranking matter, we added a performance ranking within the family in order to test if it matter most to bank-affiliated funds than to independent funds. Hence, we run the following regression, separately to bank-affiliated and independent funds,

$$
\begin{array}{r}
\text { Flow }_{i, t}=\beta_{1} \operatorname{Low}_{i, t-1}+\beta_{2} \operatorname{Mid}_{i, t-1}+\beta_{3} \text { High }_{i, t-1}+\beta_{4} \text { LowFamily }_{i, t-1} \\
\beta_{5} \text { MidFamily }_{i, t-1}+\beta_{6} \text { HighFamily }_{i, t-1}+\boldsymbol{\theta}^{\prime} \text { Controls }_{i, t-1}+\epsilon_{i, t}
\end{array}
$$

, where LowFamily, MidFamily and HighFamily are the defined by (4-1), (42), and (4-3), respectively, and computed using the 6-month gross return performance ranking within the fund family.

The results are presented in Table 7.10. Consistent with our hypothesis, the flow-performance relationship within the family is more convex to bankaffiliated funds. It shows that comparison with others funds within the family matter most to bank-affiliated funds' clients than to independent funds'. The reward to outstanding performance within family is about $100 \%-266 \%$ higher to bank-affiliated funds than to independent funds. Hence, bank-affiliated funds have more incentives to compete within family, which is consistent with these funds competing for the same flows' source.

Finally, as bank-affiliated funds offer more alternatives and as it is costly to transfer money across fund families, bank-affiliated funds' clients permute funds more intensively than independent funds'. Moreover, they swap to funds within the bank-affiliated family and not to funds outside of it. However, this costly search effect should be more concentrated on retail funds, once institutional clients may find it easier to access funds outside the institution they are currently investing. Hence, redemptions from institutional funds may not be met by inflows to other institutional funds within the family, and therefore should present weaker correlation with applications on the family level. 
In order to check the validity of our hypothesis, we disaggregate, on the family level, funds' redemptions and applications according to their investor category: retail or institutional. Then, we conduct the same analysis as in Table 7.9, where we regressed applications on redemptions, on the family level, separately to retail and institutional funds. The results, presented in Table 7.11, indicate that redemptions from institutional funds do not correlate with applications of institutional funds on the family level, for independent as well as bank-affiliated families. On the other hand, retail's redemptions and applications are much more correlated and indicate that a large portion of redemptions is reinvested in other retail funds within the family. This effect is exacerbated to bank-affiliated funds, where the estimates suggest that $R \$ 1.00$ in redemptions is associated with $\mathrm{R} \$ 0.82$ in applications in other funds within the family.

In sum, the results are consistent with our hypothesis, and show that costly search may play a role in explaining the bank-affiliated funds' "captured money". It suggests that financial institutions enjoy a market power in equity mutual funds industry, in the sense of having a captive demand for their products. Moreover, our results indicate that incentives to swap funds, such as easy access to investment alternatives, may reinforce the captured money effect. Important to notice that current account services offered as well as investors' financial literacy level may explain why bank-affiliated funds' clients are reluctant to search for other investment alternatives outside bank-affiliated fund families. 


\section{Flows' Empirical Findings and Risk Taking Implications}

In this section we explore differences in risk taking by bank-affiliated and independent funds. In the first part we show that bank-affiliated funds take less risk than independent funds, which is consistent with the flow-performance sensitivities' results. Then, in the second part we present evidences that: (1) Mutual funds' performance is increasing in active risk, measured by Active Share; and (2) Mutual funds' returns volatility, and hence the probability of bank-affiliated funds experiencing outflows is increasing in Active Share.

\section{1}

\section{Mutual Funds Risk Taking}

\subsection{1}

\section{Heterogeneous Risk Taking}

As the literature indicates that convexity is related to risk taking incentives, we surmise that bank-affiliated funds take less risk when compared to independent funds. Moreover, as bank-affiliated fund flows are more sensitive to awful performance, these funds might avoid strategies which increase their return volatility and the chances of underperforming their peers.

As a first analysis, we explore the cross-section of risk taking. Since there are many alternatives to measure portfolio risk, we focus on those that are pervasive in the literature: Tracking error, Active Share and Turnover. ${ }^{1} \mathrm{~A}$ comparison of sample means reveals that bank-affiliated funds do take less risk than independent funds, as presented in Table 7.12. It shows that bankaffiliated funds trade less (as proxied by turnover), try less to time the market (as proxied by tracking error), and are more passive (measured by active share), than independent funds. Furthermore, our results suggest that bank-affiliated equity funds are closet indexers, given that, on average, $36 \%$ of a bank-affiliated fund's portfolio composition does not differ from the market's. ${ }^{2}$

In order to control for characteristics that may affect the risk taken by mutual funds, we propose a multivariate analysis. The results are presented in

\footnotetext{
${ }^{1}$ In Chapter 2 we define and describe how we computed each risk measure used.

${ }^{2}$ It is common in the literature (8) to label a fund as closet indexer if its Active Share is less than or equal to $60 \%$.
} 
Table A.8 in Appendix. It shows that bank-affiliated funds do take less risk than independent funds, even after controlling for fund's characteristics such as size and fees charged.

Overall, our results show that bank-affiliated funds take less risk than independent funds. Consistent with more volatile flows, and hence liquidity concerns, bank-affiliated funds tilt their portfolios towards liquid assets, as those that compose the market index. Also, since less convexity in the flowperformance relationship is associated with less risk taking incentives, our results are consistent with our early findings. Finally, given that all these risk measures are positively related to performance $((7),(8))$, the results are consistent with bank-affiliated funds' underperformance.

\section{1 .2}

\section{Heterogeneous Portfolio Risk Shifting}

We also conduct tournaments' behavior tests as in (27) and (20). Our earlier findings indicate that bank-affiliated funds have less incentives to engage in mutual funds' tournaments. Therefore, relative to independent funds, bankaffiliated funds should alter less their portfolio risk profile conditionally on mid-year relative performance.

Intuitively, an independent fund manager may be more prone to increase his portfolio risk if his fund's performance is lagging behind his peers at the mid of the year, given that his fund will receive large inflows if its performance improves and do not experience outflows if it deteriorates. Therefore, he will increase his compensation if his bet pays off, and will not be penalized if it doesn't. On the other hand, a bank-affiliated fund manager experience significant outflows if his fund's performance deteriorates. Hence, his incentives to alter portfolio risk are not as strong as those of independent funds managers.

As tournaments' behavior suggest that mutual fund managers engage in yearly tournaments by changing their portfolio risk in the second part of the year, conditional on their mid-year performance, we estimate the following model:

$$
\begin{array}{r}
\Delta \overline{\text { RiskMeasure }}_{i, t}=\gamma_{1} \mathrm{R}_{i, t-1}+\gamma_{2} \mathrm{R}_{i, t-1} * \text { Bank }_{i, t-1}+\beta_{1}^{F} \mathrm{R}_{i, t-1}^{F}+ \\
\beta_{2}^{F} \mathrm{R}_{i, t-1}^{F} * \text { Bank }_{i, t-1}+\beta_{3} \text { RiskMeasure }_{i, t-1}+\beta_{4} \text { Age }_{i, t-1}+ \\
\beta_{5} \operatorname{LogTNA}_{i, t-1}+\beta_{6} \operatorname{LogFamilyTNA}_{i, t-1}+\beta_{7} \Delta \text { Flow }_{i, t-1}+\epsilon_{i, t}
\end{array}
$$

, where $\mathrm{R}_{i, t-1}$ is the fund's mid-year performance position on segment ranking, $\mathrm{R}_{i, t-1}^{F}$ is the fund's mid-year performance position on family ranking, $\Delta \overline{\text { RiskMeasure }}_{i, t}$ is the difference in fund's i risk measure between the sec- 
ond part and the first part of the year, $\mathrm{Flow}_{i, t-1}$ is the flow during the first part of the year, RiskMeasure ${ }_{i, t-1}$ is the risk measure in the first part of the year.

The regression results are presented Table 7.13. Consistent with flowperformance results, bank-affiliated fund managers alter less their portfolio risk, on average, than independent funds'. ${ }^{3}$ Moreover, as observed in the international literature, Brazilian equity mutual funds also engage in yearly tournaments: mid-year losers tend to increase more their portfolio risk than mid-year winners. The worst independent (bank-affiliated) fund managers increase (decrease) their tracking error by 0.15 (0.11) points more than the best independent (bank-affiliated) managers. Therefore, conditionally on performance, we find evidences that bank-affiliated fund managers increase their portfolio's risk less than independent funds'.

Even after controlling for risk changes due to within-family competition, we verify that bank-affiliated managers do engage less in mutual funds tournaments than independent managers: the worst independent (bank-affiliated) fund managers increase their fund's return volatility by 0.85 (0.42) points more than the best independent (bank-affiliated) managers. Hence, the worst independent fund manager increase his portfolio volatility by $101.9 \%$ more than the worst bank-affiliated fund manager. Moreover, as mid-year loser independent funds increase their Tracking Error (relative to best performing funds), bank-affiliated funds decrease theirs. Hence, consistent with our earlier results, independent funds appear to have (and respond accordingly to) more incentives to take risk than funds managed by financial institutions.

\section{2}

\section{Risk Taking and Mutual Fund Returns}

\subsection{1}

\section{Mutual Fund Performance and Active Risk}

Given that we surmised that a portion of the performance wedge between bank-affiliated and independent funds is explained by the amount of risk taken, it is crucial to check if riskier portfolios are indeed related to better performance. As a first analysis, we sort funds by Active Share and compute subsequent performance averages within deciles. The results are presented in Table 7.14. The evidences are consistent with (7): performance, measured by either gross or risk-adjusted returns, is increasing in Active Share. Notice that the gross return (4-factor alpha) difference between the High and the Low

${ }^{3}$ We present regression results obtained using as risk measure Active Share in Table A.9 in Appendix. 
Active Share portfolio is about $1.75 \%(2.59 \%)$ per year, which is about the same as the difference between independent and bank-affiliated mutual funds. Moreover, the difference between these portfolios is large not only in absolute terms, but also relatively: High portfolio's annual gross return (risk-adjusted return) is $100 \%$ (346\%) higher than the Low's, on average.

We also test if the current fund's level of Active Share is related with its subsequent performance, controlling for other fund's aspects. Hence, we run the following regression,

$$
\begin{array}{r}
\text { ExcessReturn }_{i, t, t+h}= \\
\beta_{3} \operatorname{Bank}_{i, t}+\beta_{1} \text { ExcessReturn }_{i, t-1}+\beta_{2} \operatorname{LogTNA}_{i, t-1}+ \\
\beta_{7} \text { PerformanceFee }_{i, t-1}+\beta_{8} \text { ActiveShare }_{i, t-1}+\epsilon_{i, t}
\end{array}
$$

, where ExcessReturn E $_{i, t+h}$ is the fund's i accumulated gross return in excess of Ibovespa index from month t to month $\mathrm{t}+\mathrm{h}$, Bank is a dummy which is equal to 1 if fund $\mathrm{i}$ is affiliated to a bank and 0 otherwise, and all the other control variables are defined in Appendix.

The results are presented in Table 7.15, where we measure performance using fund's gross return. ${ }^{4}$ Consistent with the literature, funds with higher Active Share level tend to present higher future returns than those funds with a lower level. The results indicate that funds whose portfolio is totally different from the market's outperform perfect indexers by $2.29 \%$ per year.

Finally, we separate funds by Active Share decile and compute the subsequent 12-month accumulated return average within deciles, as shown in Table 7.16. First, note that the number of bank-affiliated (independent) funds decrease (increase) with Active Share in a given month. More important yet, we have that $42.8 \%$ (20.7\%) of bank-affiliated (independent) funds belong to the three lowest active share deciles, in a given month. On the other hand, the number of independent (bank-affiliated) funds which, on average, have an Active Share level higher than 0.80 is $47.7 \%$ (29.2\%). Hence, while most of bank-affiliated funds are closet indexers, funds managed by stand-alone entities tend to present a high activity level.

Moreover, fund's performance is increasing in the average Active Share level. Surprisingly, the Carhart alpha from the highest decile is more than $250 \%$ higher than that of the lowest Active Share decile. Computing the average performance difference between bank-affiliated and independent funds

\footnotetext{
${ }^{4}$ In Table A.11 in Appendix we use the 4-factor Alpha as performance measure. It shows that our results are robust to the performance measure used.
} 
using Table 7.16 and comparing with the performance differences displayed in Table A.2, we can see that Active Share can account for 24.96\% (29.6\%) of the excess return (4-factor alpha) difference between bank-affiliated and independent mutual funds. ${ }^{5}$ Hence, we conclude that the lack of active risk in bank-affiliated funds' portfolios is related to a considerable portion of their underperformance relative to funds managed by stand-alone entities.

\section{2 .2}

\section{Mutual Fund's Return Volatility and Active Risk}

Finally, we show that increasing Active Share also increases fund's returns volatility. As shown in Figure 8.3, although higher Active Share is, on average, related to higher returns, it is also associated with higher return volatility. As bank-affiliated fund's clients do not tolerate volatility (and short-term underperformance), it is reasonable that these funds avoid active risk.

Given that return volatility also increases with Active Share, we have that fund's chances of being among the worst performing funds in a given month also increases with Active Share. ${ }^{6}$ In order to statistically test if the probability of underperformance increases with Active Share level, we propose a Probit analysis, where the dependent variable is a dummy which equals to 1 if the 3-month gross return percentile ranking is less than 0.2 and equals to 0 otherwise. ${ }^{7}$ The control set contains the fund's average Active Share during the previous h months (h ranges from 0 to 12 ).

We present Probit results in Table 7.17. It shows that the probability of being among the worst performing funds is increasing in the amount of active risk taken. Using the average Active Share levels displayed in Table 7.12 and computing the marginal probabilities, we have that the average independent fund have probability of 0.06 more than the average bank-affiliated fund of being among the least performers at a given month. Therefore, given that the probability of bank-affiliated funds experience outflow is increasing in the amount of active risk taken, their decision to avoid active risk is consistent with flow-performance findings.

\footnotetext{
${ }^{5}$ We use numbers from these two tables in order to compare equally-weighted averages. We present a version of Table 7.16 for TNA-weighted averages in Table A.12. Comparing the numbers there displayed with those of Table 7.2, which is also TNA-weighted, we verify that Active Share can account for $7.68 \%-10.86 \%$ of the performance difference between bank-affiliated and independent funds.

${ }^{6}$ We present this result in Table A.10 in Appendix.

${ }^{7}$ We choose the dummy this way to show that bank-affiliated funds' behavior is consistent with flow-performance relationship findings. We also define the dummy using other breakpoints, 0.3 and 0.4 , and the results are robust.
} 


\section{6 \\ Conclusion}

This paper investigates potential heterogeneities between bank-affiliated and independent funds in the Brazilian equity mutual fund industry. Using data from January 2002 to December 2016, we provide evidence that bankaffiliated underperform independent funds by $1.96 \%-2.30 \%$ per year, which is not explained by other fund's attributes, such as size or fees.

In order to explain the performance difference between bank-affiliated and independent funds, we estimate funds' flow-performance relationship, which is crucial to understand risk taking incentives. Our results suggest that bank-affiliated fund managers have less incentives to take risk and also enjoy less leeway to hold less liquid stocks in their portfolios.

Consistent with our findings, we show that bank-affiliated fund managers take less risk and engage less intensively in mutual funds' tournaments than independent funds. Moreover, bank-affiliated funds tilt their portfolios towards more liquid assets, such as those that compose the market's index, hence carrying less active risk in their portfolios. Contrary to independent funds, bank-affiliated funds are closet indexers, given that $40 \%$ of their portfolios do not differ from the market's, even though they do not label themselves as index funds.

Given that holding active risk is rewarded by increasing fund's performance, we observe that less risk taken by bank-affiliated fund managers is consistent with their underperformance relative to independent funds. More specifically, we infer that the Active Share difference between bank-affiliated and independent funds can account for $7.68-29.6 \%$ of their performance difference. Hence, a considerable portion of bank-affiliated underperformance relative to independent funds can be related to their differences in risk taking and their incentives to do so. 


\section{Bibliography}

[1] YAN, X. S.; OTHERS. The performance of investment bankaffiliated mutual funds: Conflicts of interest or informational advantage? Journal of Financial and Quantitative Analysis, 47(3):537-565, 2012.

[2] FERREIRA, M. A.; MATOS, P. P. ; PIRES, P.. Asset management within commercial banking groups: International evidence. 2016.

[3] FRANZONI, F. A.; GIANNETTI, M.. Financial conglomerate affiliated hedge funds: Risk taking behavior and liquidity transformation. 2017.

[4] DIAMOND, D. W.. Financial intermediation and delegated monitoring. The review of economic studies, 51(3):393-414, 1984.

[5] BROWN, K. C.; HARLOW, W. V. ; STARKS, L. T.. Of tournaments and temptations: An analysis of managerial incentives in the mutual fund industry. The Journal of Finance, 51(1):85-110, 1996.

[6] STEIN, J. C.. Why are most funds open-end? competition and the limits of arbitrage. The Quarterly Journal of Economics, 120(1):247-272, 2005.

[7] CREMERS, K. M.; PETAJISTO, A.. How active is your fund manager? a new measure that predicts performance. The Review of Financial Studies, 22(8):3329-3365, 2009.

[8] PÁSTOR, L.; STAMBAUGH, R. F. ; TAYLOR, L. A.. Do funds make more when they trade more? The Journal of Finance, 72(4):14831528, 2017.

[9] FANTINATTI, M.. Os fundos de ações dos grandes bancos brasileiros: Uma avaliação empírica de seus retornos e taxas de administração. 2008.

[10] MASSA, M.; REHMAN, Z.. Information flows within financial conglomerates: Evidence from the banks-mutual funds relation. Journal of Financial Economics, 89(2):288-306, 2008. 
[11] GASPAR, J.-M.; MASSA, M. ; MATOS, P.. Favoritism in mutual fund families? evidence on strategic cross-fund subsidization. The Journal of Finance, 61(1):73-104, 2006.

[12] NANDA, V.; WANG, Z. J. ; ZHENG, L.. Family values and the star phenomenon: Strategies of mutual fund families. The Review of Financial Studies, 17(3):667-698, 2004.

[13] AGARWAL, V.; MULLALLY, K. A.; TANG, Y. ; YANG, B.. Mandatory portfolio disclosure, stock liquidity, and mutual fund performance. The Journal of Finance, 70(6):2733-2776, 2015.

[14] FAMA, E. F.; FRENCH, K. R.. Common risk factors in the returns on stocks and bonds. Journal of Financial Economics, 33(1):3-56, 1993.

[15] CARHART, M. M.. On persistence in mutual fund performance. The Journal of Finance, 52(1):57-82, 1997.

[16] GIL-BAZO, J.; RUIZ-VERDÚ, P.. The relation between price and performance in the mutual fund industry. The Journal of Finance, 64(5):2153-2183, 2009.

[17] FerReiRA, M. A.; KeSWANI, A.; MIGUEL, A. F. ; RAMOS, S. B.. The determinants of mutual fund performance: A cross-country study. Review of Finance, 17(2):483-525, 2013.

[18] CHEN, J.; HONG, H.; HUANG, M. ; KUBIK, J. D.. Does fund size erode mutual fund performance? the role of liquidity and organization. The American Economic Review, 94(5):1276-1302, 2004.

[19] BERK, J. B.; GREEN, R. C.. Mutual fund flows and performance in rational markets. Journal of Political Economy, 112(6):1269-1295, 2004.

[20] CHEVALIER, J.; ELLISON, G.. Risk taking by mutual funds as a response to incentives. Journal of Political Economy, 105(6):1167-1200, 1997.

[21] JANK, S.; WEDOW, M.. Purchase and redemption decisions of mutual fund investors and the role of fund families. The European Journal of Finance, 19(2):127-144, 2013.

[22] EDELEN, R. M.. Investor flows and the assessed performance of open-end mutual funds. Journal of Financial Economics, 53(3):439-466, 1999. 
[23] SIRRI, E. R.; TUFANO, P.. Costly search and mutual fund flows. The Journal of Finance, 53(5):1589-1622, 1998.

[24] FerReIRA, M. A.; KeSWANI, A.; MIGUEL, A. F. ; RAMOS, S. B.. The flow-performance relationship around the world. Journal of Banking \& Finance, 36(6):1759-1780, 2012.

[25] JAMES, C.; KARCESKI, J.. Investor monitoring and differences in mutual fund performance. Journal of Banking \& Finance, 30(10):27872808, 2006.

[26] IPPOLITO, R. A.. Consumer reaction to measures of poor quality: Evidence from the mutual fund industry. The Journal of Law and Economics, 35(1):45-70, 1992.

[27] KEMPF, A.; RUENZI, S.. Tournaments in mutual-fund families. The Review of Financial Studies, 21(2):1013-1036, 2007.

[28] FAMA, E. F.; MACBETH, J. D.. Risk, return, and equilibrium: Empirical tests. Journal of Political Economy, 81(3):607-636, 1973. 


\section{Tables}

Table 7.1: Summary Table and Funds' Characteristics Means by Group

\begin{tabular}{lcccc}
\hline & All Funds & $\begin{array}{c}\text { Independent } \\
\text { Funds }(1)\end{array}$ & $\begin{array}{c}\text { Affiliated } \\
\text { Funds }(2)\end{array}$ & $\begin{array}{c}\text { Difference } \\
(2)-(1)\end{array}$ \\
\hline Age (Number of Years) & 6.23 & 5.60 & 7.04 & $1.44^{* * *}$ \\
Total Net Assets (R\$ million) & $(0.06)$ & $(0.05)$ & $(0.09)$ & {$[13.67]$} \\
& 50.84 & 50.87 & 50.52 & 0.35 \\
Family Total Net Assets (R\$ million) & $(1.54)$ & $(1.61)$ & $(1.46)$ & {$[0.16]$} \\
Management fee $(\%)$ & $(36.57)$ & $(68.39)$ & $(92.56)$ & {$[21.57]$} \\
& 0.80 & 0.97 & 0.66 & $-0.31^{* * *}$ \\
Performance fee $(\%)$ & $(0.01)$ & $(0.01)$ & $(0.01)$ & {$[-22.87]$} \\
End-Load fee $(\%)$ & 4.70 & 7.17 & 2.43 & $-4.74^{* * *}$ \\
& $(0.08)$ & $(0.12)$ & $(0.04)$ & {$[-37.87]$} \\
& 0.25 & 0.47 & 0.00 & $-0.47^{* * *}$ \\
& $(0.01)$ & $(0.01)$ & $(0.00)$ & {$[-50.62]$} \\
\hline
\end{tabular}

Notes: This table presents summary statistics on Brazilian equity mutual funds. Data was obtained from CVM through Quantum Finance platform, and consists of all Brazilian equity mutual funds (FIAs), excluding FIC funds ("Fundos de Investimento em Cotas"), Master funds, Index funds and Privatization funds, over January 2002 to December 2016. For each feature, within each group, we calculate its TNA-weighted average for each month. Then, we compute its time series average, which is displayed on the table. Total Net Assets is measured as the net assets under management in millions in December 2016 prices. Fund Family is the entity responsible for the fund management. As an example, Bradesco fund family in a given month corresponds to the unit involving all funds managed by Bradesco in that month. Family Total Net Assets is the sum of Total Net Assets of the funds that compose the family at a given month, also measured in millions and in December 2016 prices. The other variables are defined in Table A.13 in Appendix. The values without brackets or parentheses are the averages, and those inside parentheses are the averages' standard deviation. The values inside the brackets are the t-statistic obtained from sample mean test whose null hypothesis is that there is no difference across group means. ${ }^{* * *},{ }^{* *}$, and $*$ indicate significance at $1 \%, 5 \%$, and $10 \%$ level (two-tailed tests), respectively. 


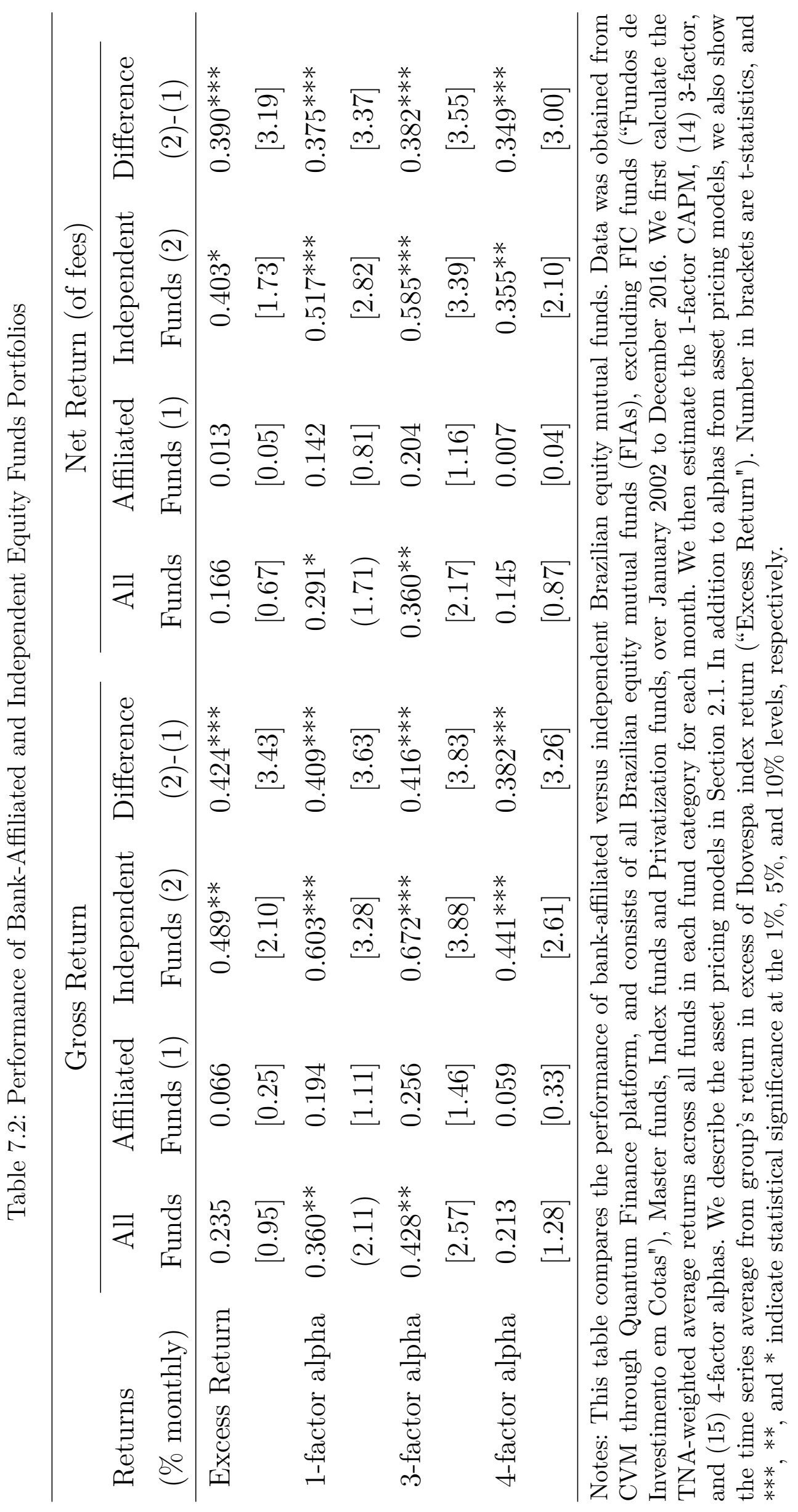


Table 7.3: Monthly Panel Regressions of Fund Performance

\begin{tabular}{|c|c|c|c|c|}
\hline & \multicolumn{4}{|c|}{ Dependent Variable (\%) } \\
\hline & $\begin{array}{l}\text { Excess Return } \\
\text { (from Ibovespa) }\end{array}$ & $\begin{array}{l}\text { 1-factor } \\
\text { Alpha }\end{array}$ & $\begin{array}{c}\text { 3-factor } \\
\text { Alpha }\end{array}$ & $\begin{array}{l}\text { 4-factor } \\
\text { Alpha }\end{array}$ \\
\hline \multirow[t]{2}{*}{ Bank dummy } & $-0.163^{* * *}$ & $-0.167^{* * *}$ & $-0.163^{* * *}$ & $-0.192^{* * *}$ \\
\hline & {$[-3.511]$} & {$[-3.694]$} & {$[-3.845]$} & {$[-4.590]$} \\
\hline \multirow[t]{2}{*}{ Lagged Return Measure } & $0.057^{* * *}$ & $0.032^{* *}$ & 0.016 & 0.013 \\
\hline & {$[3.460]$} & {$[2.245]$} & {$[1.091]$} & {$[0.870]$} \\
\hline \multirow[t]{2}{*}{ Log TNA } & $0.064^{* * *}$ & $0.077^{* * *}$ & $0.077^{* * *}$ & $0.066^{* * *}$ \\
\hline & {$[3.914]$} & {$[5.009]$} & {$[5.223]$} & {$[4.682]$} \\
\hline \multirow[t]{2}{*}{ Log Family TNA } & 0.012 & 0.013 & 0.011 & $0.018^{*}$ \\
\hline & {$[1.088]$} & {$[1.114]$} & {$[1.019]$} & {$[1.823]$} \\
\hline \multirow[t]{2}{*}{ Flow } & $0.928^{* * *}$ & $0.569^{*}$ & $0.624^{* *}$ & $0.752^{* * *}$ \\
\hline & {$[3.362]$} & {$[1.952]$} & {$[2.325]$} & {$[3.060]$} \\
\hline \multirow[t]{2}{*}{ Age } & $-0.007^{* *}$ & -0.004 & $-0.008^{* *}$ & $-0.009^{* * *}$ \\
\hline & {$[-2.273]$} & {$[-1.161]$} & {$[-2.521]$} & {$[-2.852]$} \\
\hline \multirow[t]{2}{*}{ Management Fee } & $0.006^{* *}$ & $0.006^{* *}$ & 0.004 & $0.004^{*}$ \\
\hline & {$[2.462]$} & {$[2.328]$} & {$[1.362]$} & {$[1.825]$} \\
\hline \multirow[t]{2}{*}{ Performance Fee } & 0.179 & 0.179 & $0.367^{* *}$ & $0.342^{* *}$ \\
\hline & {$[1.027]$} & {$[1.069]$} & {$[2.480]$} & {$[2.284]$} \\
\hline \multirow[t]{2}{*}{ Tracking Error } & $-0.104^{* * *}$ & $-0.123^{* * *}$ & $-0.094^{* * *}$ & $-0.094^{* * *}$ \\
\hline & {$[-4.909]$} & {$[-4.842]$} & {$[-4.312]$} & {$[-4.459]$} \\
\hline Observations & 79,063 & 64,795 & 64,795 & 64,795 \\
\hline R-squared & 0.526 & 0.425 & 0.428 & 0.421 \\
\hline Month FE & Yes & Yes & Yes & Yes \\
\hline
\end{tabular}

Notes: This table presents results for the panel regressions of fund monthly performance for Brazilian equity mutual funds. Data was obtained from CVM through Quantum Finance platform, and consists of all Brazilian equity mutual funds (FIAs), excluding FIC funds ("Fundos de Investimento em Cotas"), Master funds, Index funds and Privatization funds, over January 2002 to December 2016. Each column represents Equation 3-4 with a different dependent variable: (1) Fund's return in excess of Ibovespa index; (2) 1-factor Alpha; (3) 3 -factor Alpha; and (4) 4-factor Alpha. The performance measures computation process is described in Subsection 2.2. All control variables are lagged by one period. Variable definitions are provided in Table A.13 in the Appendix. Robust t-statistics adjusted for clustering at the month level are reported in parentheses. ${ }^{*}, * *, * * *$ indicate statistical significance at the $10 \%$, $5 \%$, and $1 \%$ levels, respectively. 
Table 7.4: Panel Regressions of Fund Family Performance

\begin{tabular}{lcccc}
\hline & \multicolumn{4}{c}{ Dependent Variable } \\
\cline { 2 - 5 } & $\begin{array}{c}\text { Excess Return } \\
\text { (from Ibovespa) }\end{array}$ & $\begin{array}{c}\text { Alfactor } \\
\text { Bank }\end{array}$ & Alpha & Alpha \\
\hline Bank Dummy & $-0.266^{* * *}$ & $-0.272^{* * *}$ & $-0.246^{* * *}$ & $-0.226^{* * *}$ \\
Log Family TNA & {$[-4.467]$} & {$[-4.654]$} & {$[-4.421]$} & {$[-4.182]$} \\
& $0.081^{* * *}$ & $0.093^{* * *}$ & $0.086^{* * *}$ & $0.082^{* * *}$ \\
Family Management Fee & {$[6.928]$} & {$[7.554]$} & {$[7.328]$} & {$[7.221]$} \\
& -0.007 & -0.030 & -0.021 & -0.011 \\
Family Flow & {$[-0.328]$} & {$[-1.376]$} & {$[-0.977]$} & {$[-0.528]$} \\
& 0.021 & $0.047^{* * *}$ & $0.046^{* * *}$ & $0.049 * * *$ \\
Family Performance Fee & {$[0.985]$} & {$[4.132]$} & {$[3.812]$} & {$[4.130]$} \\
& $-0.004^{*}$ & $-0.008^{* * *}$ & $-0.005^{*}$ & -0.003 \\
Family Age & {$[-1.699]$} & {$[-2.966]$} & {$[-1.853]$} & {$[-1.378]$} \\
& $-0.020^{* * *}$ & $-0.015^{* *}$ & $-0.018^{* * *}$ & $-0.018^{* * *}$ \\
& {$[-3.275]$} & {$[-2.333]$} & {$[-2.944]$} & {$[-3.021]$} \\
Observations & & & & \\
R-squared & 27,008 & 20,939 & 20,939 & 20,939 \\
Month FE & 0.543 & 0.445 & 0.447 & 0.438 \\
\hline
\end{tabular}

Notes: This table presents results for the panel regressions of fund monthly performance for Brazilian equity mutual funds. Data was obtained from CVM through Quantum Finance platform, and consists of all Brazilian equity mutual funds (FIAs), excluding FIC funds ("Fundos de Investimento em Cotas"), Master funds, Index funds and Privatization funds, over January 2002 to December 2016. Each column represents Equation (3-4) with a different dependent variable: (1) Fund's return in excess of Ibovespa index; (2) 1-factor Alpha; (3) 3-factor Alpha; and (4) 4-factor Alpha. Fund Family is the entity responsible for the fund management. As an example, Bradesco fund family in a given month corresponds to the unit involving all funds managed by Bradesco in that month. In order to obtain family level characteristics, every month, for each fund family we compute the equally weighted average of each feature, using all funds that are composing the family at that month. To compute fund family's alpha we repeat the process described in Section 2.2. All control variables are lagged by one period. Variable definitions are provided in Table A.13 in the Appendix ??. Robust t-statistics are reported in parentheses. ${ }^{*}, * *, * *$ indicate statistical significance at the $10 \%, 5 \%$, and $1 \%$ levels, respectively. 
Table 7.5: Unconditional Flow Volatility Among Independent and BankAffiliated Funds

\begin{tabular}{|c|c|c|c|c|c|}
\hline \multicolumn{6}{|c|}{ Average Fund's Flow Unconditional Volatility by Category } \\
\hline \multirow[b]{2}{*}{ Investor Category } & \multicolumn{2}{|c|}{$\begin{array}{l}\text { Independent Funds } \\
\text { (1) }\end{array}$} & \multicolumn{2}{|c|}{$\begin{array}{l}\text { Bank-Affiliated Funds } \\
\text { (2) }\end{array}$} & \multirow[t]{2}{*}{$\begin{array}{l}\text { Difference } \\
(2)-(1) \\
\end{array}$} \\
\hline & Mean $(\%)$ & Obs & Mean (\%) & Obs & \\
\hline All Categories & 9.986 & 734 & 10.378 & 461 & $\begin{array}{c}0.392 \\
{[1.384]}\end{array}$ \\
\hline Exclusive & 9.129 & 247 & 9.257 & 206 & $\begin{array}{c}0.128 \\
{[0.284]}\end{array}$ \\
\hline Qualified Investor & 11.379 & 71 & 13.370 & 23 & $\begin{array}{c}1.991 \\
{[1.379]}\end{array}$ \\
\hline Pension & 8.258 & 153 & 9.434 & 92 & $\begin{array}{c}1.175^{* *} \\
{[2.138]}\end{array}$ \\
\hline General Investor & 11.352 & 256 & 11.998 & 106 & $\begin{array}{c}0.646 \\
{[1.321]}\end{array}$ \\
\hline Institutional & 12.101 & 6 & 12.831 & 20 & $\begin{array}{c}0.730 \\
{[0.366]}\end{array}$ \\
\hline
\end{tabular}

Notes: This table presents results for the panel regressions of fund monthly performance for Brazilian equity mutual funds. Data was obtained from CVM through Quantum Finance platform, and consists of all Brazilian equity mutual funds (FIAs), excluding FIC funds ("Fundos de Investimento em Cotas"), Master funds, Index funds and Privatization funds, over January 2002 to December 2016. For each fund, we calculate its flow standard deviation using all the time series, where flow is the measure proposed by (23). Then, within each investor category and group (bank-affiliated or independent), we calculate the equally weighted flow volatility average, which are displayed on the table. Robust t-statistics are reported in parentheses. * **, *** indicate statistical significance at the $10 \%, 5 \%$, and $1 \%$ levels, respectively. 
Table 7.6: Heterogeneous Flow-Performance Relationship

\begin{tabular}{|c|c|c|c|c|}
\hline \multicolumn{5}{|c|}{ Percentile Rank Based On J-month Gross Return } \\
\hline & \multicolumn{4}{|c|}{ Flow $_{t}$} \\
\hline & $\mathrm{J}=3$ & $\mathrm{~J}=6$ & $\mathrm{~J}=9$ & $\mathrm{~J}=12$ \\
\hline \multirow[t]{2}{*}{$\operatorname{Low}_{t-1}$} & -0.009 & -0.010 & -0.024 & -0.024 \\
\hline & {$[-0.523]$} & {$[-0.581]$} & {$[-1.485]$} & {$[-1.392]$} \\
\hline \multirow[t]{2}{*}{$\operatorname{Mid}_{t-1}$} & $0.011^{* * *}$ & $0.012^{* * *}$ & $0.015 * * *$ & $0.014^{* * *}$ \\
\hline & {$[3.150]$} & {$[3.566]$} & {$[4.099]$} & {$[4.374]$} \\
\hline \multirow{2}{*}{$\operatorname{High}_{t-1}$} & $0.069 * * *$ & $0.091^{* * *}$ & $0.085 * * *$ & $0.089 * * *$ \\
\hline & {$[4.541]$} & {$[5.859]$} & {$[6.304]$} & {$[7.271]$} \\
\hline \multirow{2}{*}{ Bank $^{*}$ Low $_{t-1}$} & $0.040 * *$ & $0.053 * * *$ & $0.047 * *$ & $0.032^{*}$ \\
\hline & [2.044] & {$[2.774]$} & [2.528] & [1.758] \\
\hline \multirow{2}{*}{$\operatorname{Bank}^{*} \operatorname{Mid}_{t-1}$} & 0.000 & 0.001 & 0.000 & 0.000 \\
\hline & {$[0.011]$} & {$[0.345]$} & [0.058] & {$[0.045]$} \\
\hline \multirow[t]{2}{*}{ Bank $^{*} \operatorname{High}_{t-1}$} & 0.029 & 0.029 & 0.009 & 0.005 \\
\hline & {$[1.334]$} & [1.288] & {$[0.402]$} & {$[0.221]$} \\
\hline \multirow[t]{2}{*}{ Bank dummyt } & $-0.010 * * *$ & $-0.012^{* * *}$ & $-0.009 * * *$ & $-0.006^{*}$ \\
\hline & {$[-2.968]$} & {$[-3.467]$} & {$[-2.814]$} & {$[-1.854]$} \\
\hline \multirow{2}{*}{$\log \mathrm{TNA}_{t-1}$} & $-0.004^{* * *}$ & $-0.003^{* * *}$ & $-0.003 * * *$ & $-0.003^{* * *}$ \\
\hline & {$[-11.110]$} & {$[-10.330]$} & {$[-9.494]$} & {$[-8.635]$} \\
\hline \multirow[t]{2}{*}{ Log Family $\mathrm{TNA}_{t-1}$} & $0.001^{* *}$ & $0.001^{*}$ & $0.001 *$ & $0.001^{* *}$ \\
\hline & [2.592] & [1.952] & [1.881] & {$[2.078]$} \\
\hline \multirow[t]{2}{*}{$\operatorname{Age}_{t-1}$} & $-0.001^{* * *}$ & $-0.001^{* * *}$ & $-0.001 * * *$ & $-0.001^{* * *}$ \\
\hline & {$[-9.826]$} & {$[-8.446]$} & {$[-7.661]$} & {$[-6.449]$} \\
\hline \multirow[t]{2}{*}{ Flow $_{t-1}$} & -0.015 & -0.028 & -0.036 & -0.036 \\
\hline & {$[-0.399]$} & {$[-0.764]$} & {$[-0.981]$} & {$[-0.965]$} \\
\hline \multirow[t]{2}{*}{ Number of funds $s_{t-1}$} & $-0.001^{* * *}$ & $-0.001^{* * *}$ & $-0.001 * * *$ & $-0.001^{* *}$ \\
\hline & {$[-2.892]$} & {$[-2.759]$} & {$[-2.617]$} & {$[-2.538]$} \\
\hline \multirow{2}{*}{ Flow Classification $t$} & $0.281^{* * *}$ & $0.273 * * *$ & $0.273^{* * *}$ & $0.274^{* * *}$ \\
\hline & {$[11.469]$} & {$[11.908]$} & {$[12.000]$} & {$[11.891]$} \\
\hline Observations & 89,365 & 85,814 & 82,262 & 78,710 \\
\hline R-squared & 0.156 & 0.157 & 0.158 & 0.156 \\
\hline Fund Style FE & Yes & Yes & Yes & Yes \\
\hline Month FE & Yes & Yes & Yes & Yes \\
\hline
\end{tabular}

Notes: This table presents results for the panel regressions of monthly flows on performance ranking and controls. Data was obtained from CVM through Quantum Finance platform, and consists of all Brazilian equity mutual funds (FIAs), excluding FIC funds ("Fundos de Investimento em Cotas"), Master funds, Index funds and Privatization funds, over January 2002 to December 2016. Each column represents Equation (4-4) using rankings based on 3, 6, 9 and 12-month accumulated gross return. Variable definitions are provided in Table A.13 in the Appendix. Robust t-statistics adjusted for clustering at the month level are reported in parentheses. ${ }^{*}, * *, * * *$ indicate statistical significance at the $10 \%, 5 \%$, and $1 \%$ levels, respectively. 


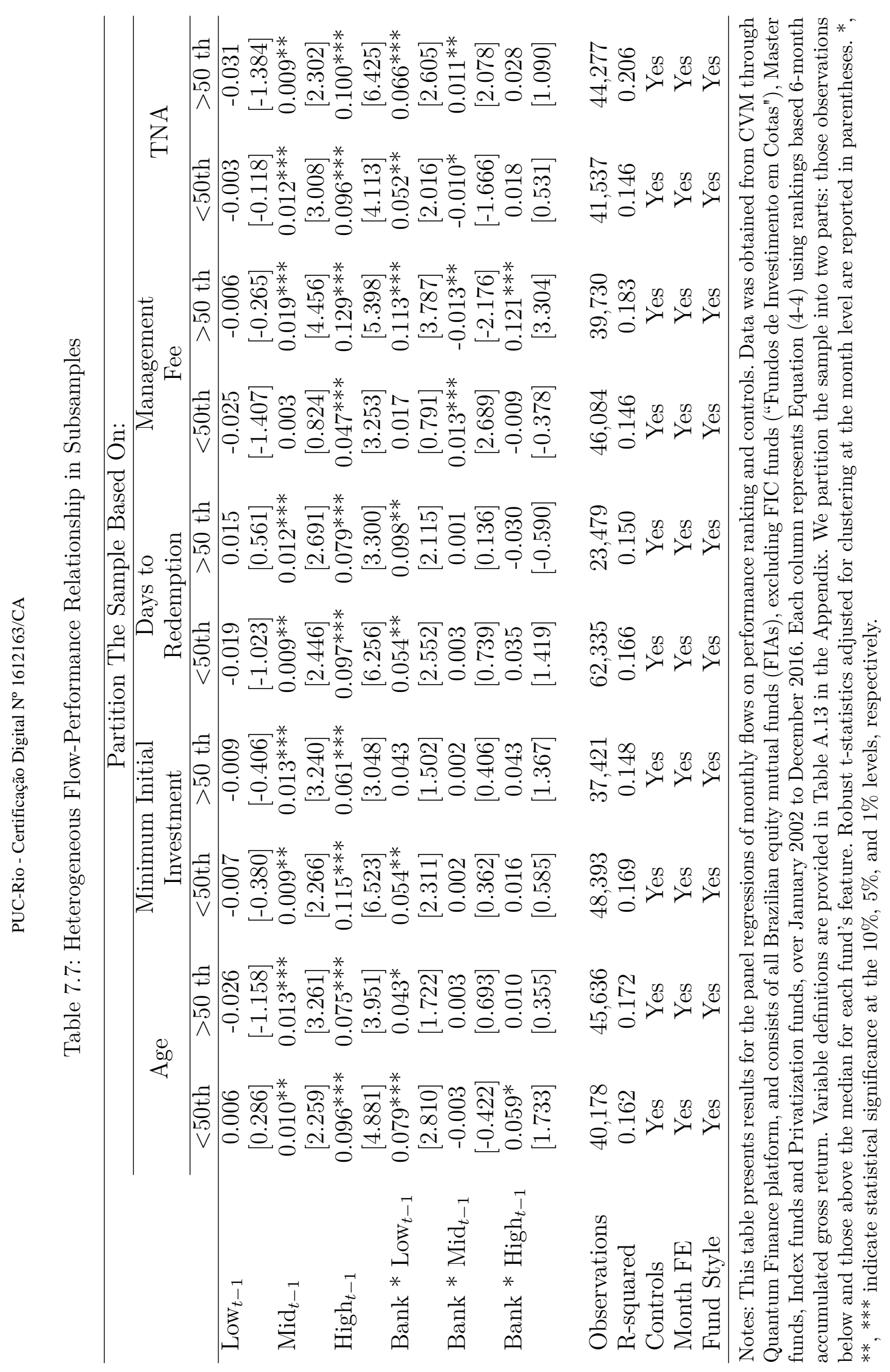




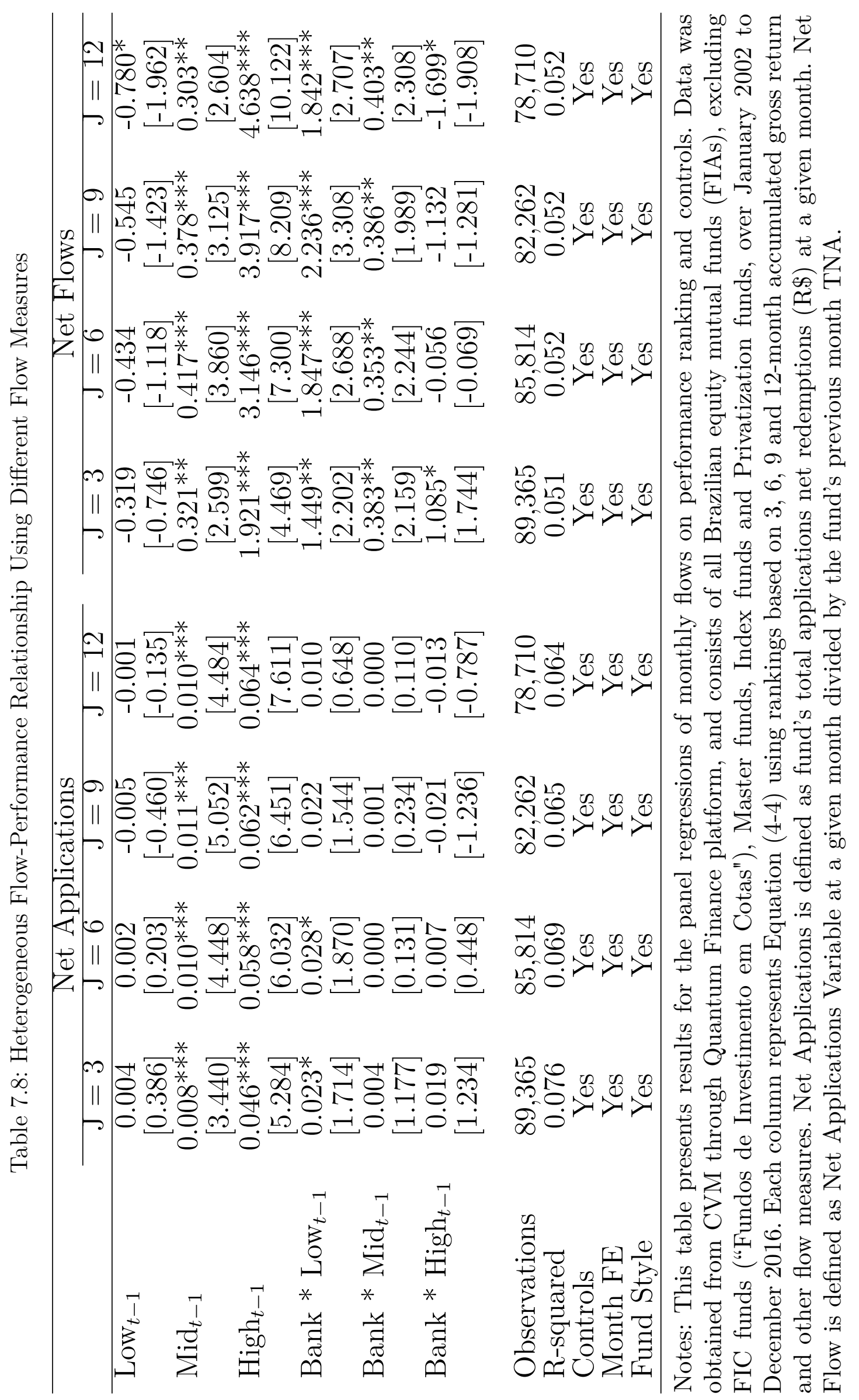




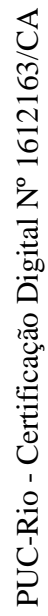

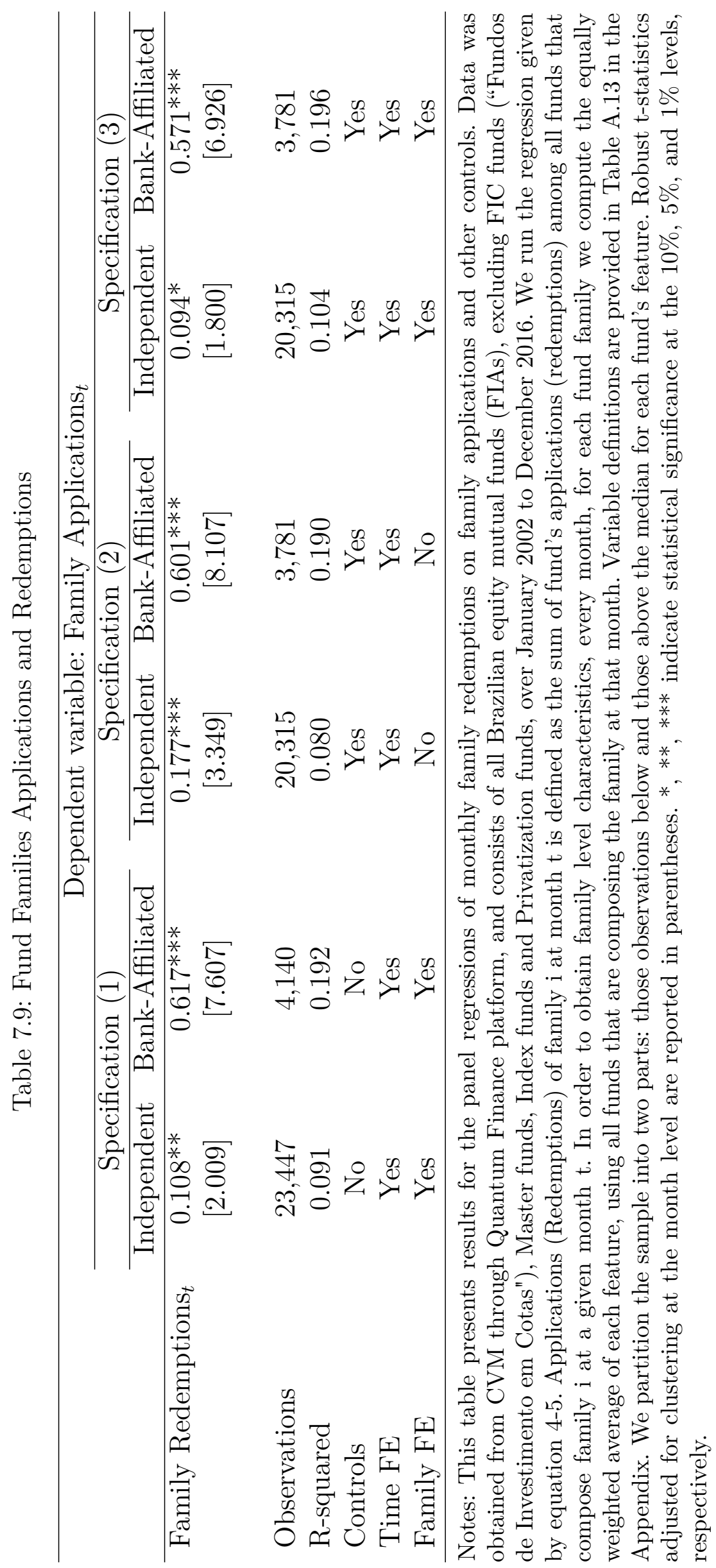


Table 7.10: Flow-performance Relationship Within the Family

\begin{tabular}{|c|c|c|c|c|}
\hline & \multicolumn{2}{|c|}{ Flows $_{t}$} & \multicolumn{2}{|c|}{ Net Flows $t$} \\
\hline & $\begin{array}{l}\text { Independent } \\
\text { Funds }\end{array}$ & $\begin{array}{c}\text { Bank-Affiliated } \\
\text { Funds }\end{array}$ & $\begin{array}{l}\text { Independent } \\
\text { Funds }\end{array}$ & $\begin{array}{c}\text { Bank-Affiliated } \\
\text { Funds }\end{array}$ \\
\hline \multirow[t]{2}{*}{$\operatorname{Low}_{t-1}$} & -0.017 & $0.038^{* *}$ & -0.011 & $0.023^{*}$ \\
\hline & {$[-0.835]$} & {$[2.580]$} & {$[-0.796]$} & {$[1.828]$} \\
\hline \multirow[t]{2}{*}{$\operatorname{Mid}_{t-1}$} & $0.012^{* * *}$ & 0.005 & $0.011^{* * *}$ & 0.003 \\
\hline & {$[3.641]$} & {$[1.335]$} & {$[4.124]$} & [0.922] \\
\hline \multirow[t]{2}{*}{$\operatorname{High}_{t-1}$} & $0.095^{* * *}$ & $0.095^{* * *}$ & $0.064^{* * *}$ & $0.050^{* * *}$ \\
\hline & {$[5.653]$} & {$[4.331]$} & {$[5.781]$} & {$[2.705]$} \\
\hline \multirow[t]{2}{*}{ Low Family F $_{t-1}$} & 0.002 & 0.005 & -0.001 & 0.012 \\
\hline & {$[0.253]$} & {$[0.512]$} & {$[-0.166]$} & [1.139] \\
\hline \multirow[t]{2}{*}{ Mid Family $_{t-1}$} & $-0.008^{* *}$ & 0.004 & -0.004 & 0.006 \\
\hline & {$[-2.239]$} & {$[0.987]$} & [-1.127] & [1.640] \\
\hline \multirow{2}{*}{ High Family $_{t-1}$} & $0.018^{* *}$ & $0.048^{* * *}$ & $0.016^{*}$ & $0.032^{* * *}$ \\
\hline & {$[2.125]$} & {$[3.703]$} & {$[1.961]$} & {$[2.855]$} \\
\hline Observations & 36,839 & 35,793 & 36,839 & 35,793 \\
\hline R-squared & 0.141 & 0.181 & 0.058 & 0.079 \\
\hline Controls & Yes & Yes & Yes & Yes \\
\hline Time FE & Yes & Yes & Yes & Yes \\
\hline Style FE & Yes & Yes & Yes & Yes \\
\hline
\end{tabular}

Notes: This table presents results for the panel regressions of monthly flows on performance ranking and controls. Data was obtained from CVM through Quantum Finance platform, and consists of all Brazilian equity mutual funds (FIAs), excluding FIC funds ("Fundos de Investimento em Cotas"), Master funds, Index funds and Privatization funds, over January 2002 to December 2016. We estimate Equation (4-6), separately to bank-affiliated funds and to independent funds. We used performance rankings based on 6-month accumulated gross return within the fund's segment and within the fund's family and other controls. Flows is the flow measure proposed by (23). Net Applications is defined as fund's total applications net redemptions ( $\$$ ) at a given month. Net flows is defined as Net Applications Variable at a given month divided by the fund's previous month TNA. The control set is the same as in Table 7.6, and variable definitions are given in Table A.13 in Appendix. Robust t-statistics adjusted for clustering at the month level are reported in parentheses. $*, * *, * * *$ indicate statistical significance at the $10 \%, 5 \%$, and $1 \%$ levels, respectively. 
Table 7.11: Fund Families Applications and Redemptions by Investor Category

\begin{tabular}{|c|c|c|c|c|c|c|}
\hline \multicolumn{7}{|c|}{ Panel A - Independent Funds Families Flows } \\
\hline \multirow[b]{3}{*}{ Family Redemptions $s_{t}$} & \multicolumn{6}{|c|}{ Dependent Variable: Family Applications ${ }_{t}$} \\
\hline & \multicolumn{3}{|c|}{ Retail Funds } & \multicolumn{3}{|c|}{ Institutional Funds } \\
\hline & $\begin{array}{c}0.316^{* * *} \\
{[7.518]}\end{array}$ & $\begin{array}{c}0.389^{* * *} \\
{[9.392]}\end{array}$ & $\begin{array}{c}0.232^{* * *} \\
{[5.266]}\end{array}$ & $\begin{array}{c}0.062 \\
{[0.956]}\end{array}$ & $\begin{array}{c}0.156^{* *} \\
{[2.396]}\end{array}$ & $\begin{array}{c}0.062 \\
{[0.929]}\end{array}$ \\
\hline Observation & 12,704 & 11,265 & 11,265 & 8,906 & 7,588 & 7,588 \\
\hline R-squared & 0.393 & 0.404 & 0.456 & 0.075 & 0.057 & 0.081 \\
\hline Controls & No & Yes & Yes & No & Yes & Yes \\
\hline Time FE & Yes & Yes & Yes & Yes & Yes & Yes \\
\hline Family FE & Yes & No & Yes & Yes & No & Yes \\
\hline
\end{tabular}

Panel B - Bank-Affiliated Funds Families Flows

\begin{tabular}{lcccccc}
\hline & \multicolumn{5}{c}{ Dependent Variable: Family Applications } \\
\cline { 2 - 7 } & \multicolumn{3}{c}{ Retail Funds } & \multicolumn{4}{c}{ Institutional Funds } \\
\hline Family Redemptions $t$ & $0.895^{* * *}$ & $0.827^{* * *}$ & $0.819^{* * *}$ & 0.113 & 0.055 & 0.132 \\
& {$[12.226]$} & {$[12.579]$} & {$[11.068]$} & {$[1.081]$} & {$[0.738]$} & {$[1.187]$} \\
Observations & 2,779 & 2,563 & 2,563 & 1,334 & 1,194 & 1,194 \\
R-squared & 0.615 & 0.632 & 0.635 & 0.120 & 0.111 & 0.119 \\
Controls & No & Yes & Yes & No & Yes & Yes \\
Time FE & Yes & Yes & Yes & Yes & Yes & Yes \\
Family FE & Yes & No & Yes & Yes & No & Yes \\
\hline
\end{tabular}

Notes: This table presents results for the panel regressions of monthly family redemptions on family applications and other controls. Data was obtained from CVM through Quantum Finance platform, and consists of all Brazilian equity mutual funds (FIAs), excluding FIC funds ("Fundos de Investimento em Cotas"), Master funds, Index funds and Privatization funds, over January 2002 to December 2016. We run the regression proposed by equation 4-5, on fund family level, separately to retail funds and to institutional funds. Applications (Redemptions) of family i at month t is defined as the sum of fund's applications (redemptions) among all funds that compose family $i$ at a given month $t$. In order to obtain family level characteristics, every month, for each fund family we compute the equally weighted average of each feature, using all funds that are composing the family at that month. Variable definitions are provided in Table A.13 in the Appendix. We partition the sample into two parts: those observations below and those above the median for each fund's feature. Robust t-statistics adjusted for clustering at the month level are reported in parentheses. $*, * *, * * *$ indicate statistical significance at the $10 \%$, $5 \%$, and $1 \%$ levels, respectively. 
Table 7.12: Unconditional Differences in Risk Taking by Equity Mutual Funds

\begin{tabular}{lccc}
\hline \multirow{2}{*}{ Risk Measure } & $\begin{array}{c}\text { Independent } \\
\text { Funds }(1)\end{array}$ & $\begin{array}{c}\text { Bank-Affiliated } \\
\text { Funds }(2)\end{array}$ & $\begin{array}{c}\text { Difference } \\
(2)-(1)\end{array}$ \\
\hline Active Share $(\%)$ & 76.02 & 64.43 & $-11.59^{* * *}$ \\
Tracking Error $(\beta=1)$ & $(0.36)$ & $(0.29)$ & {$[-25.33]$} \\
& $(0.68$ & 4.18 & $-0.50^{* * *}$ \\
Tracking Error $(\hat{\beta})$ & 4.04 & $(0.13)$ & {$[-3.01]$} \\
Turnover $(\%)$ & $(0.11)$ & 3.67 & $-0.37^{* *}$ \\
& 18.20 & $(0.13)$ & {$[-2.13]$} \\
& $(1.99)$ & 9.35 & $-8.85^{* * *}$ \\
& & $(0.27)$ & {$[-4.42]$} \\
\hline
\end{tabular}

Notes: This table presents results for the unconditional average differences in risk taking by bank-affiliated and independent mutual funds. Data was obtained from CVM through Quantum Finance platform, and consists of all Brazilian equity mutual funds (FIAs), excluding FIC funds ("Fundos de Investimento em Cotas"), Master funds, Index funds and Privatization funds, over January 2002 to December 2016. For each risk measure, within each group (bank-affiliated and independent) we computed the TNA-weighted average, every month. Then, we computed its time series average, which we display on this Table. Risk measures are defined in the Chapter 2. Robust t-statistics are reported in parentheses. *, **, $* * *$ indicate statistical significance at the $10 \%, 5 \%$, and $1 \%$ levels, respectively. 
Table 7.13: Brazilian Equity Mutual Funds' Tournament Behavior

\begin{tabular}{|c|c|c|c|}
\hline \multicolumn{4}{|c|}{ Dependent Variable: $\Delta \sigma_{i, t}$} \\
\hline \multirow[t]{2}{*}{ Bank Dummy } & -0.008 & $-0.160^{* *}$ & $-0.204^{* *}$ \\
\hline & {$[-0.088]$} & {$[-1.978]$} & {$[-2.348]$} \\
\hline \multirow{2}{*}{$\operatorname{Rank}_{i, t-1}$} & $-0.661^{* * *}$ & $-0.787 * * *$ & $-0.848^{* * *}$ \\
\hline & {$[-6.910]$} & {$[-9.579]$} & {$[-7.606]$} \\
\hline \multirow{2}{*}{$\operatorname{Bank}_{i, t-1} * \operatorname{Rank}_{i, t-1}$} & -0.029 & 0.114 & $0.428 * *$ \\
\hline & {$[-0.189]$} & {$[0.858]$} & {$[2.185]$} \\
\hline \multirow{2}{*}{$\operatorname{Rank}_{i, t-1}^{F}$} & & & -0.105 \\
\hline & & & {$[-1.247]$} \\
\hline \multirow{2}{*}{$\operatorname{Bank}_{i, t-1} * \operatorname{Rank}_{i, t-1}^{F}$} & & & -0.187 \\
\hline & & & {$[-1.154]$} \\
\hline Observations & 7,022 & 6,781 & 5,750 \\
\hline \multirow[t]{2}{*}{ R-squared } & 0.562 & 0.676 & 0.684 \\
\hline & Dependen & $\Delta$ Trackin & \\
\hline \multirow[t]{2}{*}{ Bank Dummy } & $-0.227^{* *}$ & $-0.437 * * *$ & $-0.475 * * *$ \\
\hline & {$[-2.516]$} & {$[-4.980]$} & {$[-5.009]$} \\
\hline \multirow[t]{2}{*}{$\operatorname{Rank}_{i, t-1}$} & 0.032 & $-0.151^{*}$ & $-0.229^{*}$ \\
\hline & {$[0.337]$} & {$[-1.694]$} & {$[-1.890]$} \\
\hline \multirow{2}{*}{$\operatorname{Bank}_{i, t-1} * \operatorname{Rank}_{i, t-1}$} & 0.048 & $0.259^{*}$ & $0.676^{* * *}$ \\
\hline & {$[0.307]$} & {$[1.796]$} & {$[3.173]$} \\
\hline \multirow[t]{2}{*}{$\operatorname{Rank}_{i, t-1}^{F}$} & & & -0.109 \\
\hline & & & {$[-1.198]$} \\
\hline \multirow{2}{*}{$\operatorname{Bank}_{i, t-1}{ }^{*} \operatorname{Rank}_{i, t-1}^{F}$} & & & $-0.321^{*}$ \\
\hline & & & {$[-1.820]$} \\
\hline Observations & 7,022 & 6,781 & 5,750 \\
\hline R-squared & 0.788 & 0.830 & 0.834 \\
\hline Controls & No & Yes & Yes \\
\hline Month FE & Yes & Yes & Yes \\
\hline Fund Style FE & No & Yes & Yes \\
\hline
\end{tabular}

Notes: This table presents results for the panel regressions of semi-annual changes in fund's risk. Data was obtained from CVM through Quantum Finance platform, and consists of all Brazilian equity mutual funds (FIAs), excluding FIC funds ("Fundos de Investimento em Cotas"), Master funds, Index funds and Privatization funds, over January 2002 to December 2016. The regressions results are from Equation (5-1) using OLS. $\Delta \sigma_{i, t}$ is the difference between the second semester and first (of year $\mathrm{t}$ ) semester fund's return volatility. $\Delta$ Tracking Error $_{i, t}$ is the difference between the second and the first semester (of year t) fund's i tracking error with Ibovespa index $(\beta=1)$. Risk measures are defined in the Chapter 2. Variable definitions are provided in Table A.13 in the Appendix. Robust t-statistics are reported in parentheses. ${ }^{*}, * *, * *$ indicate statistical significance at the $10 \%, 5 \%$, and $1 \%$ levels, respectively. 


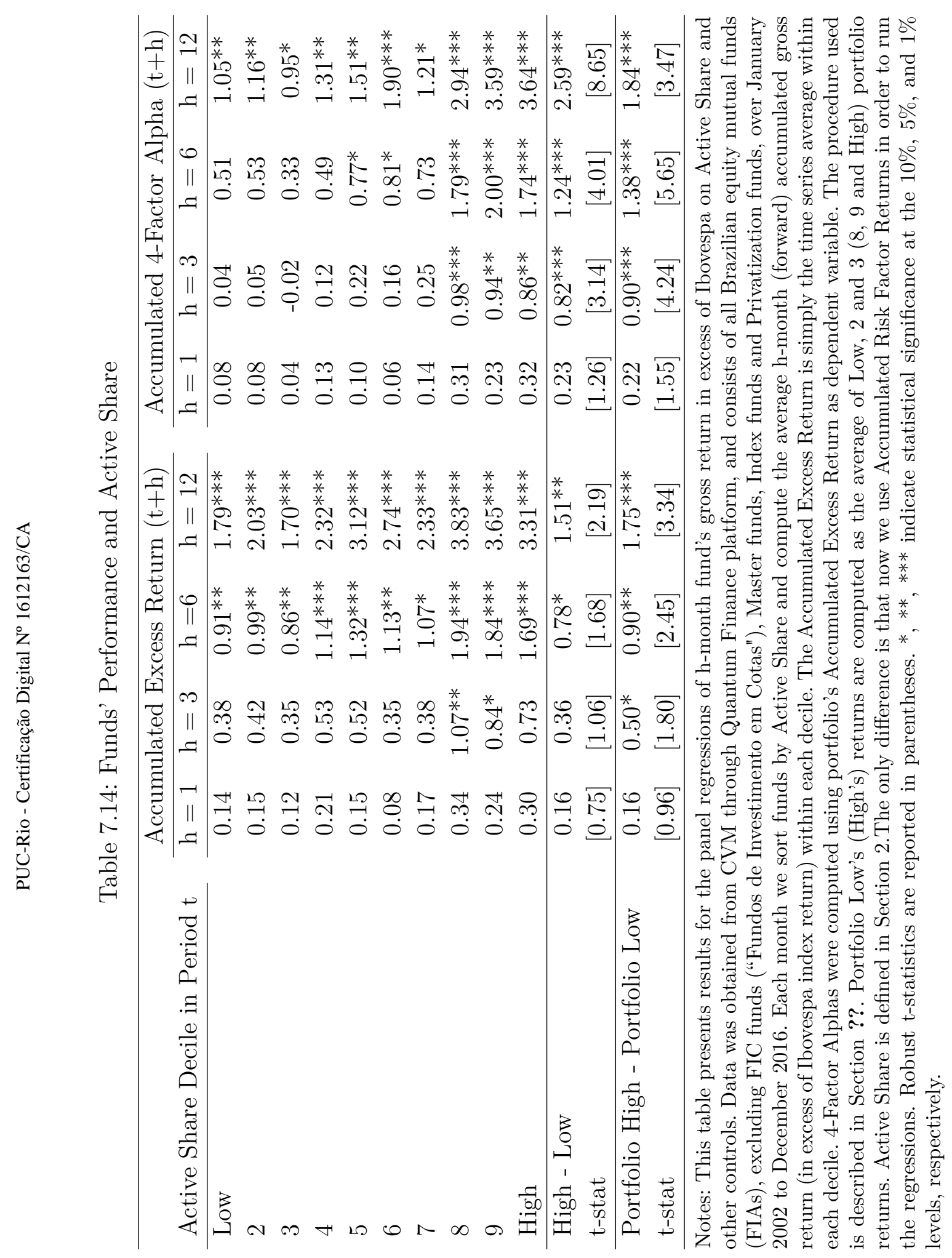


Table 7.15: Active Share and Fund's Performance

\begin{tabular}{lccccc}
\hline & \multicolumn{5}{c}{ Dependent Variable: Excess Return R $_{t+h}$} \\
\cline { 2 - 7 } Bank Dummy & $\mathrm{h}=0$ & $\mathrm{~h}=3$ & $\mathrm{~h}=6$ & $\mathrm{~h}=9$ & $\mathrm{~h}=12$ \\
\hline & $-0.128^{* * *}$ & $-0.227^{* * *}$ & $-0.534^{* * *}$ & $-0.965^{* * *}$ & $-1.458^{* * *}$ \\
Excess Return & {$[-3.403]$} & {$[-4.162]$} & {$[-6.294]$} & {$[-13.109]$} & {$[-18.795]$} \\
& $0.057^{* *}$ & $1.113^{* * *}$ & $1.216^{* * *}$ & $1.271^{* * *}$ & $1.303^{* * *}$ \\
Log TNA & {$[2.689]$} & {$[39.987]$} & {$[21.244]$} & {$[16.105]$} & {$[15.058]$} \\
& $0.051^{* *}$ & $0.142^{* * *}$ & $0.451^{* * *}$ & $0.770^{* * *}$ & $1.077^{* * *}$ \\
Log Family TNA & {$[3.075]$} & {$[5.483]$} & {$[8.758]$} & {$[13.868]$} & {$[28.276]$} \\
& $0.025^{* *}$ & $0.044^{* * *}$ & $0.107^{* * *}$ & $0.193^{* * *}$ & $0.309^{* * *}$ \\
Flow & {$[2.516]$} & {$[3.708]$} & {$[3.717]$} & {$[7.250]$} & {$[9.778]$} \\
& 0.648 & 0.534 & 3.170 & 4.378 & $4.945^{*}$ \\
Age & {$[0.587]$} & {$[0.248]$} & {$[1.292]$} & {$[1.616]$} & {$[1.815]$} \\
& -0.002 & $-0.009^{*}$ & $-0.023^{* * *}$ & $-0.040^{* * *}$ & $-0.057^{* * *}$ \\
Management Fee & {$[-0.647]$} & {$[-1.845]$} & {$[-4.052]$} & {$[-6.656]$} & {$[-8.791]$} \\
& $0.005^{* *}$ & $0.011^{* * *}$ & $0.027^{* * *}$ & $0.028^{* *}$ & $0.028^{* *}$ \\
Performance Fee & {$[2.523]$} & {$[3.927]$} & {$[4.554]$} & {$[2.770]$} & {$[2.940]$} \\
& 0.224 & 0.471 & $1.267^{* *}$ & $2.531^{* * *}$ & $4.146^{* * *}$ \\
Active Share & {$[1.011]$} & {$[1.224]$} & {$[3.045]$} & {$[5.244]$} & {$[7.807]$} \\
& 0.136 & 0.296 & $1.093^{*}$ & $1.781^{* *}$ & $2.288^{* * *}$ \\
Observations & {$[0.384]$} & {$[0.542]$} & {$[1.908]$} & {$[2.504]$} & {$[4.465]$} \\
R-squared & & & & & \\
Month Fixed Effects & 70,234 & 70,048 & 67,177 & 64,286 & 61,364 \\
Classification Fixed Effects & 0.550 & 0.618 & 0.444 & 0.387 & 0.345 \\
\hline
\end{tabular}

Notes: This table presents results for the panel regressions of h-month fund's gross return in excess of Ibovespa on Active Share and other controls. Data was obtained from CVM through Quantum Finance platform, and consists of all Brazilian equity mutual funds (FIAs), excluding FIC funds ("Fundos de Investimento em Cotas"), Master funds, Index funds and Privatization funds, over January 2002 to December 2016. The regression results in this table comes from equation (5-2) estimates using OLS. All controls are lagged by one period. Risk measures are defined in the Chapter 2. Variable definitions are provided in Table A.13 in the Appendix. Robust t-statistics are reported in parentheses. *, **, *** indicate statistical significance at the $10 \%, 5 \%$, and $1 \%$ levels, respectively. 


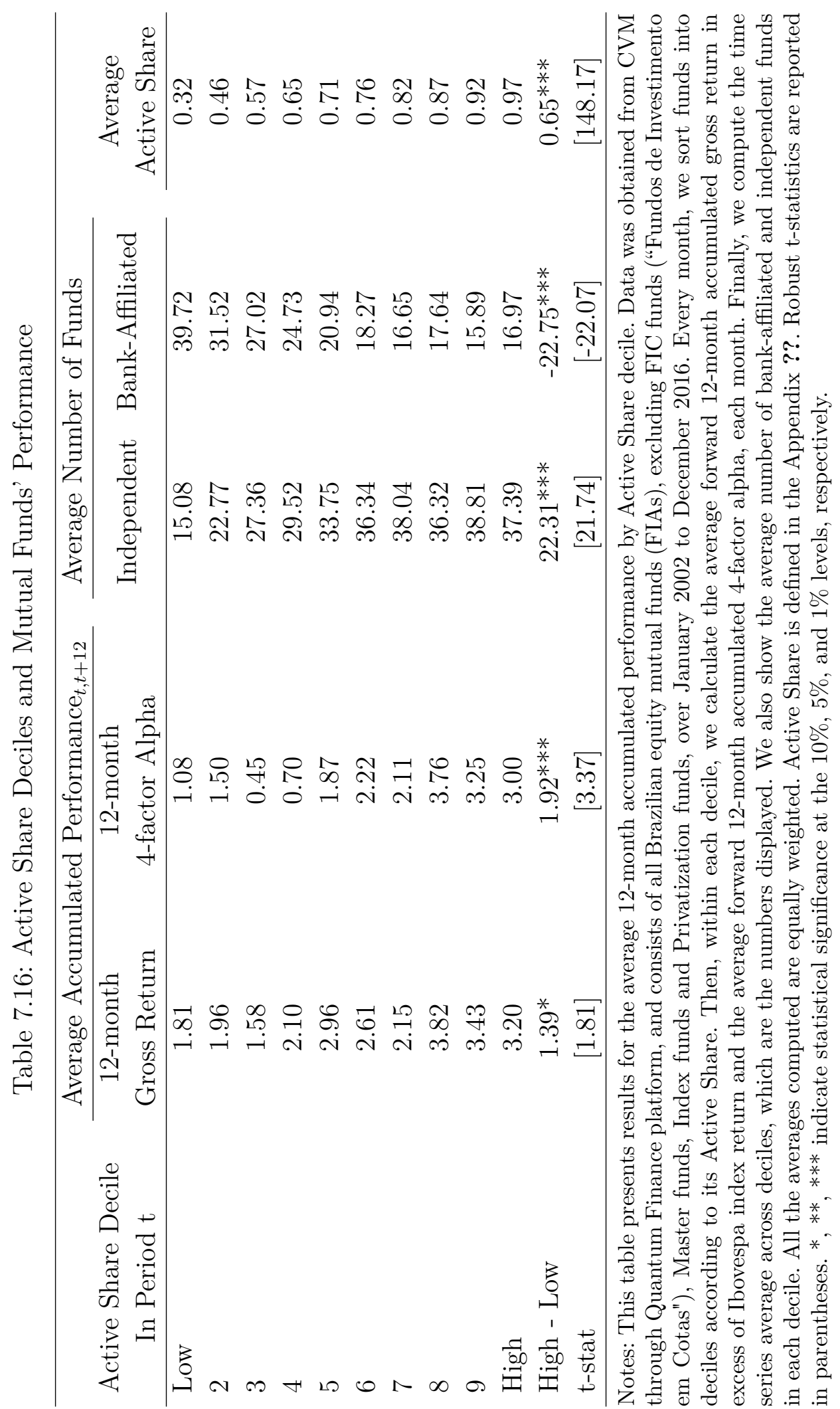


Table 7.17: Active Share and Probability of Underperformance

\begin{tabular}{lcccc}
\hline & \multicolumn{3}{c}{ Dependent Variable: Underperformance Dummy } \\
\cline { 2 - 5 } & $\mathrm{h}=3$ & $\mathrm{~h}=6$ & $\mathrm{~h}=9$ & $\mathrm{~h}=12$ \\
\hline Bank Dummy & $0.068^{* * *}$ & $0.089^{* * *}$ & $0.149^{* * *}$ & $0.166^{* * *}$ \\
& {$[2.889]$} & {$[3.930]$} & {$[5.987]$} & {$[6.218]$} \\
Avg. Active Share ${ }_{t-1, t-h}$ & $1.075^{* * *}$ & $0.952^{* * *}$ & $0.888^{* * *}$ & $0.732^{* * *}$ \\
& {$[7.791]$} & {$[7.528]$} & {$[7.200]$} & {$[5.837]$} \\
Gross Return $t-h$ & $-2.162^{* * *}$ & $-2.348^{* * *}$ & $-2.032^{* * *}$ & $-2.047^{* * *}$ \\
& {$[-3.348]$} & {$[-3.325]$} & {$[-2.978]$} & {$[-2.917]$} \\
Log TNA & $-0.065^{* * *}$ & $-0.095^{* * *}$ & $-0.109^{* * *}$ & $-0.117^{* * *}$ \\
& {$[-11.466]$} & {$[-16.777]$} & {$[-18.108]$} & {$[-20.141]$} \\
Log Family TNA & $-0.033^{* * *}$ & $-0.037^{* * *}$ & $-0.044^{* * *}$ & $-0.056^{* * *}$ \\
& {$[-6.661]$} & {$[-6.988]$} & {$[-7.832]$} & {$[-9.093]$} \\
Flow & -0.064 & $-0.342^{*}$ & -0.269 & -0.257 \\
Age & {$[-0.378]$} & {$[-1.942]$} & {$[-1.559]$} & {$[-1.488]$} \\
Management Fee & $0.005^{* * *}$ & $0.006^{* * *}$ & $0.005^{* * *}$ & $0.004^{* * *}$ \\
& {$[4.449]$} & {$[4.935]$} & {$[4.230]$} & {$[3.572]$} \\
Performance Fee & -0.126 & -0.045 & 0.016 & 0.029 \\
& {$[-1.464]$} & {$[-0.575]$} & {$[0.188]$} & {$[0.364]$} \\
Observations & $-0.497^{* * *}$ & $-0.437^{* * *}$ & $-0.481^{* * *}$ & $-0.530^{* * *}$ \\
Month FE & {$[-5.576]$} & {$[-4.720]$} & {$[-4.574]$} & {$[-4.990]$} \\
Classification FE & 6860 & 64,047 & 60,249 & 56,583 \\
\hline
\end{tabular}

Notes: This table presents results for the panel Probit analysis of funds' relative performance ranking on controls and Active Share. Data was obtained from CVM through Quantum Finance platform, and consists of all Brazilian equity mutual funds (FIAs), excluding FIC funds ("Fundos de Investimento em Cotas"), Master funds, Index funds and Privatization funds, over January 2002 to December 2016. The dependent variable is a dummy which is equal to 1 if the fund's performance ranking (based on previous 3 months gross returns) is less than 0.2 and equal to 0 otherwise. Avg. Active Share is the fund's average Active Share in the previous h months. Acc Gross Return is the fund's h-month accumulated gross return. All controls are lagged by one period. Active Share is defined in the Appendix ?? Variable definitions are provided in Table A.13 in the Appendix. Robust t-statistics are reported in parentheses. ${ }^{*}, * *, * *$ indicate statistical significance at the $10 \%, 5 \%$, and $1 \%$ levels, respectively. 
8

\section{Figures}

Figure 8.1: Flows and Relative Performance of Bank-Affiliated and Independent Funds

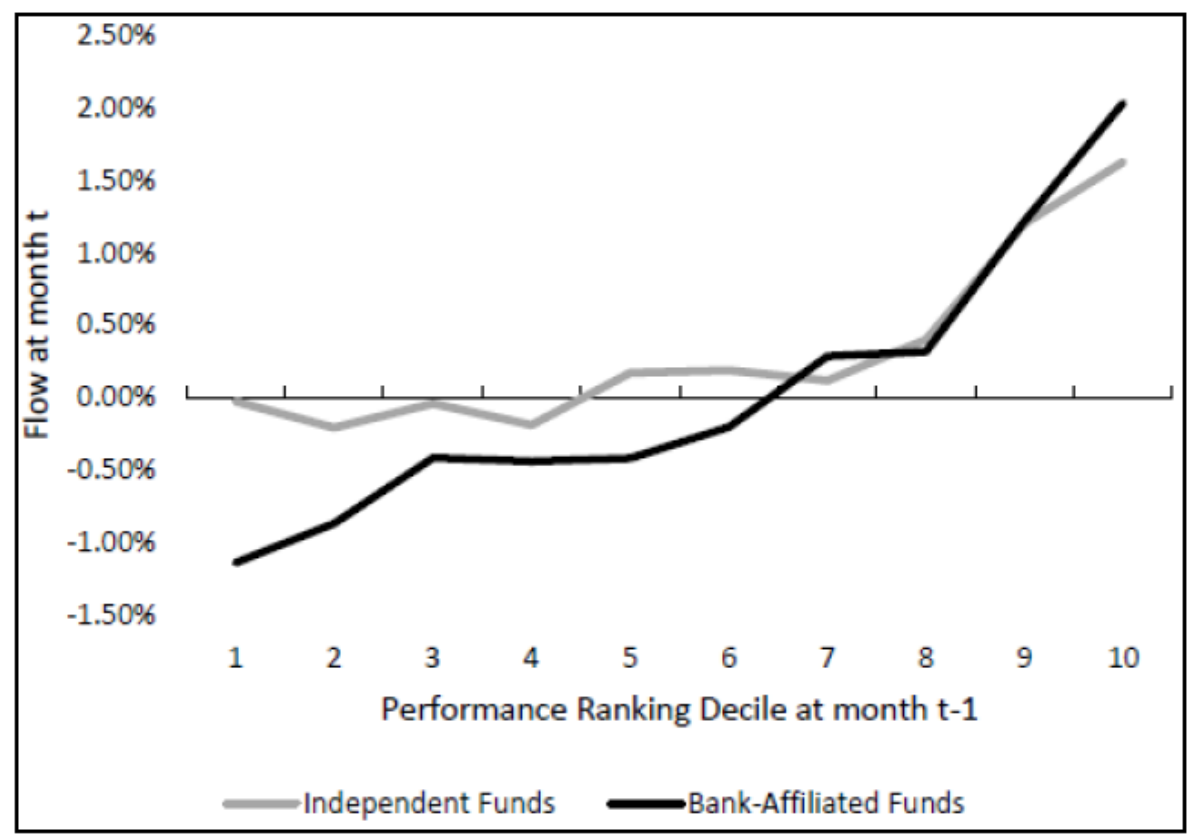

Notes: This figure shows the flow-performance relationship of bank-affiated and independent funds. The performance ranking used is based on the 6-month gross return computed within funds' segments. Then, within each group (bank-affiliated and independent), we computed, within each quintile, the equally weighted average in the next month, every month. The results presented are the time series average within each quintile, for each group. 
Figure 8.2: Number of Mutual Funds Sold by Fund Families

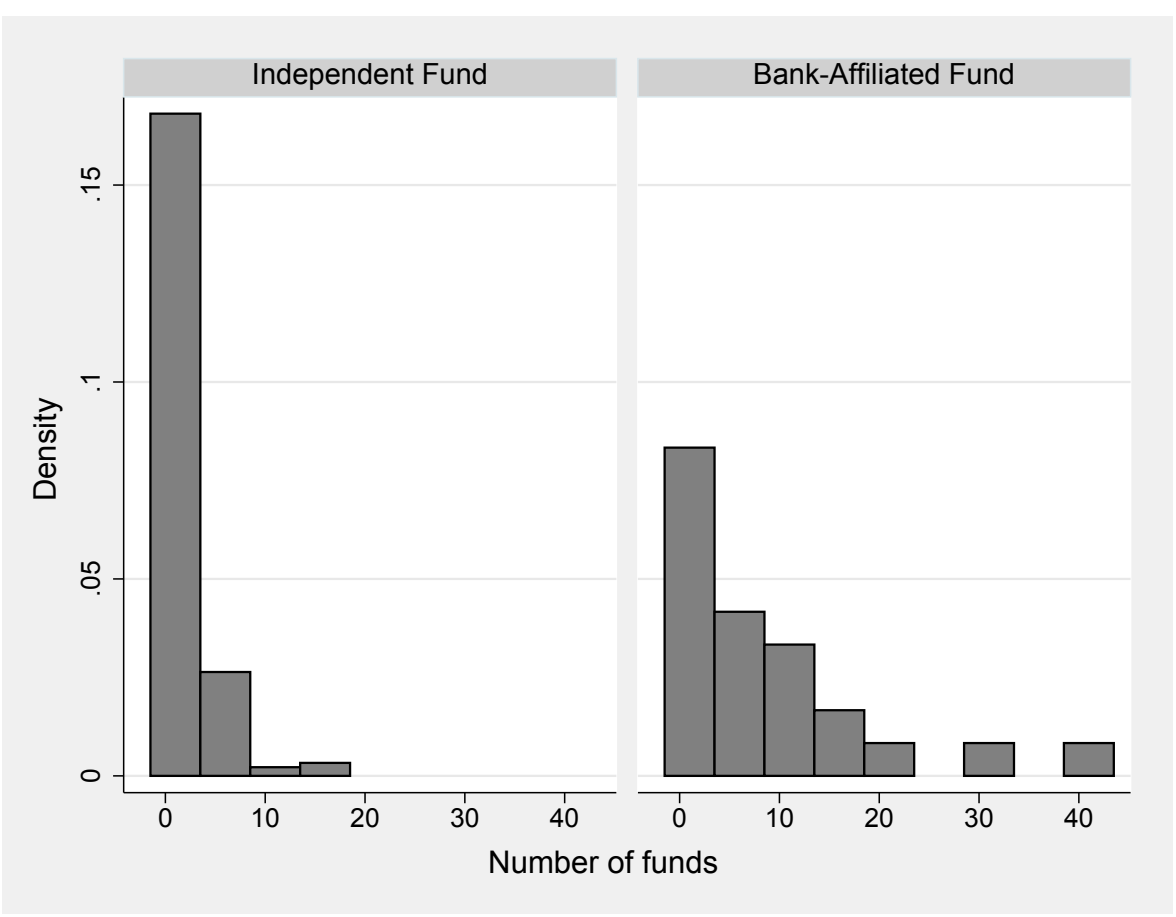

Notes: This figure shows the average number of funds offered by bank-affiliated and independent fund families. For each month, within each group (bank-affiliated and independent), we computed the equally weighted average of the fund family size (measured by number of funds). Then, we computed the time series average within each group, which we show on this Figure.

Figure 8.3: Fund's Returns Volatility and Active Share

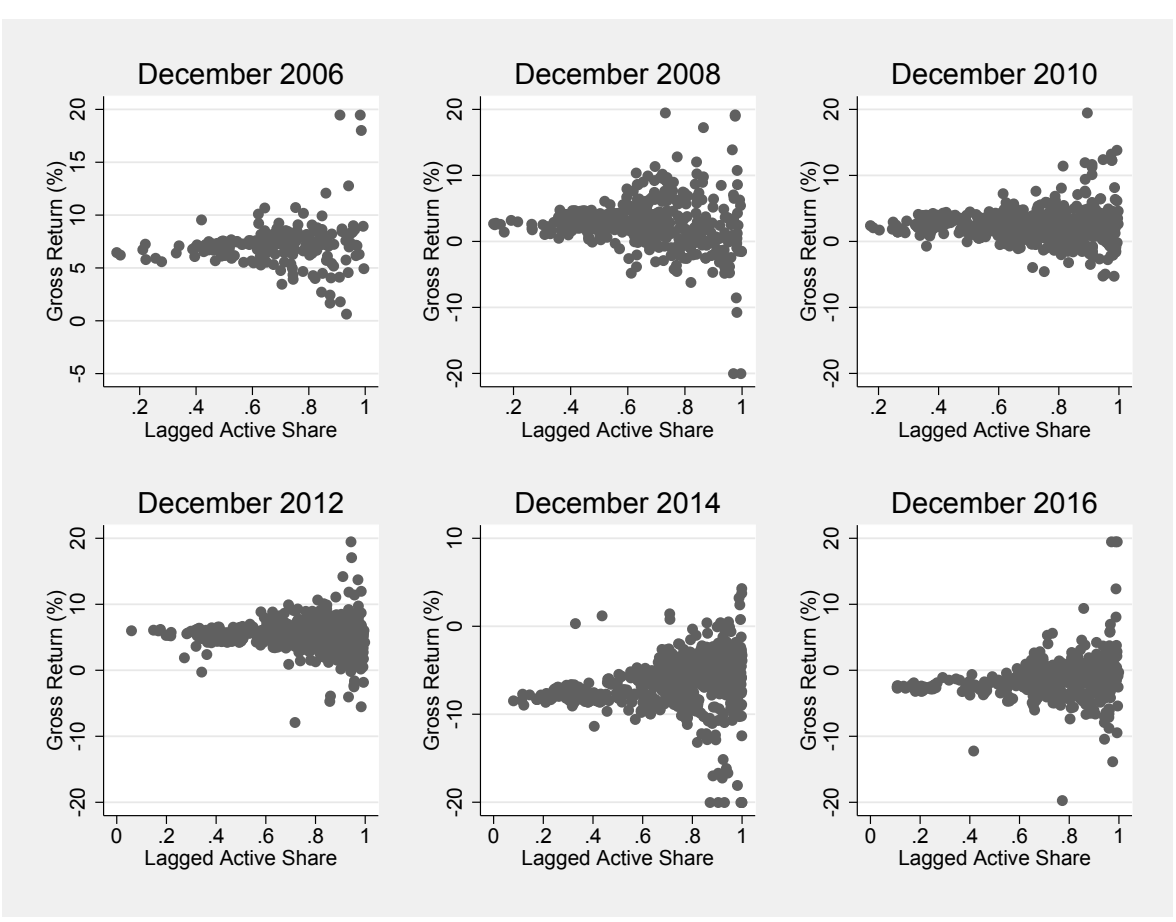

Notes: This figure shows the relation between Active Share and Funds' return distribution. Specifically, we plot, for each even year of our sample, we plot the observed funds' gross returns in December versus funds' Active Share in November. 


\section{Appendix}

Table A.1: Brazilian Mutual Fund Industry Evolution Over 2002-2016

\begin{tabular}{|c|c|c|c|c|c|c|}
\hline \multirow[b]{2}{*}{ Year } & \multicolumn{3}{|c|}{ Number of Funds } & \multicolumn{3}{|c|}{ Total Net Assets ( $\mathrm{R} \$$ Billions) } \\
\hline & $\begin{array}{c}\text { All } \\
\text { Funds }\end{array}$ & $\begin{array}{l}\text { Independent } \\
\text { Funds }\end{array}$ & $\begin{array}{c}\text { Bank-Affiliated } \\
\text { Funds }\end{array}$ & $\begin{array}{c}\text { All } \\
\text { Funds }\end{array}$ & $\begin{array}{l}\text { Independent } \\
\text { Funds }\end{array}$ & $\begin{array}{c}\text { Bank-Affiliated } \\
\text { Funds }\end{array}$ \\
\hline 2002 & 138 & 53 & 85 & 2.14 & 0.63 & 1.51 \\
\hline 2003 & 152 & 60 & 92 & 3.94 & 1.38 & 2.55 \\
\hline 2004 & 182 & 74 & 108 & 5.33 & 2.16 & 3.17 \\
\hline 2005 & 214 & 96 & 118 & 7.22 & 3.02 & 4.20 \\
\hline 2006 & 274 & 130 & 144 & 14.35 & 7.26 & 7.09 \\
\hline 2007 & 388 & 182 & 206 & 29.40 & 13.60 & 15.80 \\
\hline 2008 & 527 & 261 & 266 & 21.20 & 9.84 & 11.36 \\
\hline 2009 & 628 & 327 & 301 & 36.31 & 18.34 & 17.97 \\
\hline 2010 & 743 & 412 & 331 & 42.48 & 23.52 & 18.96 \\
\hline 2011 & 801 & 473 & 328 & 42.26 & 25.65 & 16.60 \\
\hline 2012 & 835 & 508 & 327 & 53.77 & 32.65 & 21.12 \\
\hline 2013 & 882 & 560 & 322 & 60.57 & 39.57 & 21.00 \\
\hline 2014 & 871 & 570 & 301 & 57.65 & 38.02 & 19.63 \\
\hline 2015 & 758 & 504 & 254 & 49.86 & 32.87 & 16.98 \\
\hline 2016 & 637 & 423 & 214 & 57.84 & 39.68 & 18.16 \\
\hline
\end{tabular}

Notes: This table presents the number of funds and the total net assets under management (December $2016 \mathrm{R} \$$ Billions) of the Brazilian equity mutual fund industry in December of every year since 2002. Data was obtained from CVM through Quantum Finance platform, and consists of all Brazilian equity mutual funds (FIAs), excluding FIC funds ("Fundos de Investimento em Cotas"), Master funds, Index funds and Privatization funds, over January 2002 to December 2016. 


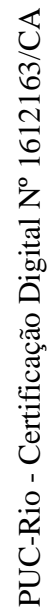

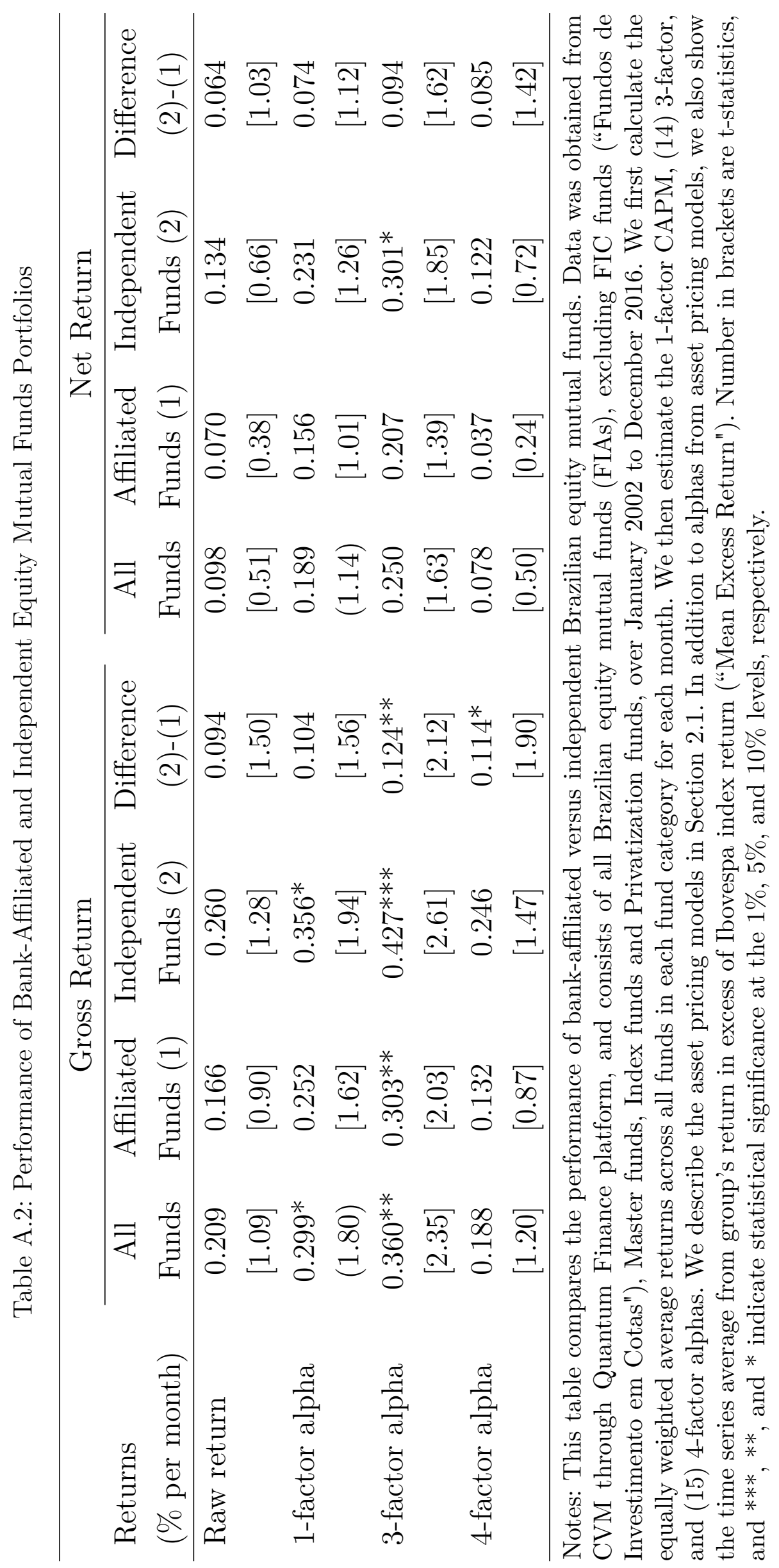


Table A.3: Panel Regressions of Fund Family Performance

\begin{tabular}{lcccc}
\hline & \multicolumn{4}{c}{ Dependent Variable } \\
\cline { 2 - 5 } & $\begin{array}{l}\text { Excess Return } \\
\text { (from Ibovespa) }\end{array}$ & $\begin{array}{c}\text { Alpha } \\
\text { Bactor }\end{array}$ & $\begin{array}{c}3 \text {-factor } \\
\text { Alpha }\end{array}$ & $\begin{array}{c}\text { Alfactor } \\
\text { Bank Dummy }\end{array}$ \\
\hline \multirow{2}{*}{ Log Family TNA } & $-0.235^{* * *}$ & $-0.256^{* * *}$ & $-0.235^{* * *}$ & $-0.215^{* * *}$ \\
& {$[-4.336]$} & {$[-4.782]$} & {$[-4.599]$} & {$[-4.337]$} \\
Family Management Fee & $0.075^{* * *}$ & $0.086^{* * *}$ & $0.079^{* * *}$ & $0.077^{* * *}$ \\
& {$[6.938]$} & {$[7.565]$} & {$[7.355]$} & {$[7.355]$} \\
Family Flow & -1.436 & $-3.678^{* *}$ & $-3.533^{* *}$ & $-2.897^{*}$ \\
& {$[-0.816]$} & {$[-2.043]$} & {$[-2.055]$} & {$[-1.739]$} \\
Family Performance Fee & $0.033^{* * *}$ & $0.036^{* *}$ & $0.036^{* *}$ & $0.037^{* *}$ \\
& {$[3.387]$} & {$[2.354]$} & {$[2.285]$} & {$[2.472]$} \\
Family Age & -0.379 & $-0.720^{* * *}$ & -0.336 & -0.163 \\
& {$[-1.480]$} & {$[-2.697]$} & {$[-1.325]$} & {$[-0.663]$} \\
Observations & $-0.021^{* * *}$ & $-0.016^{* *}$ & $-0.016^{* * *}$ & $-0.015^{* *}$ \\
R-squared & {$[-3.612]$} & {$[-2.535]$} & {$[-2.713]$} & {$[-2.542]$} \\
Month FE & & & & \\
\hline
\end{tabular}

Notes: This table presents results for the panel regressions of fund family monthly performance. Data was obtained from CVM through Quantum Finance platform, and consists of all Brazilian equity mutual funds (FIAs), excluding FIC funds ("Fundos de Investimento em Cotas"), Master funds, Index funds and Privatization funds, over January 2002 to December 2016. Each column represents Equation (3-4) with a different dependent variable: (1) Fund's return in excess of Ibovespa index; (2) 1-factor Alpha; (3) 3-factor Alpha; and (4) 4-factor Alpha. In order to obtain family level characteristics, every month, for each fund family we compute the TNA-weighted average of each feature, using all funds that are composing the family at that month. To compute fund family's alpha we repeat the process described in Section 2.2. All control variables are lagged by one period. Variable definitions are provided in Table A.13 in the Appendix. Robust t-statistics are reported in parentheses. *, **, *** indicate statistical significance at the $10 \%$, $5 \%$, and $1 \%$ levels, respectively. 


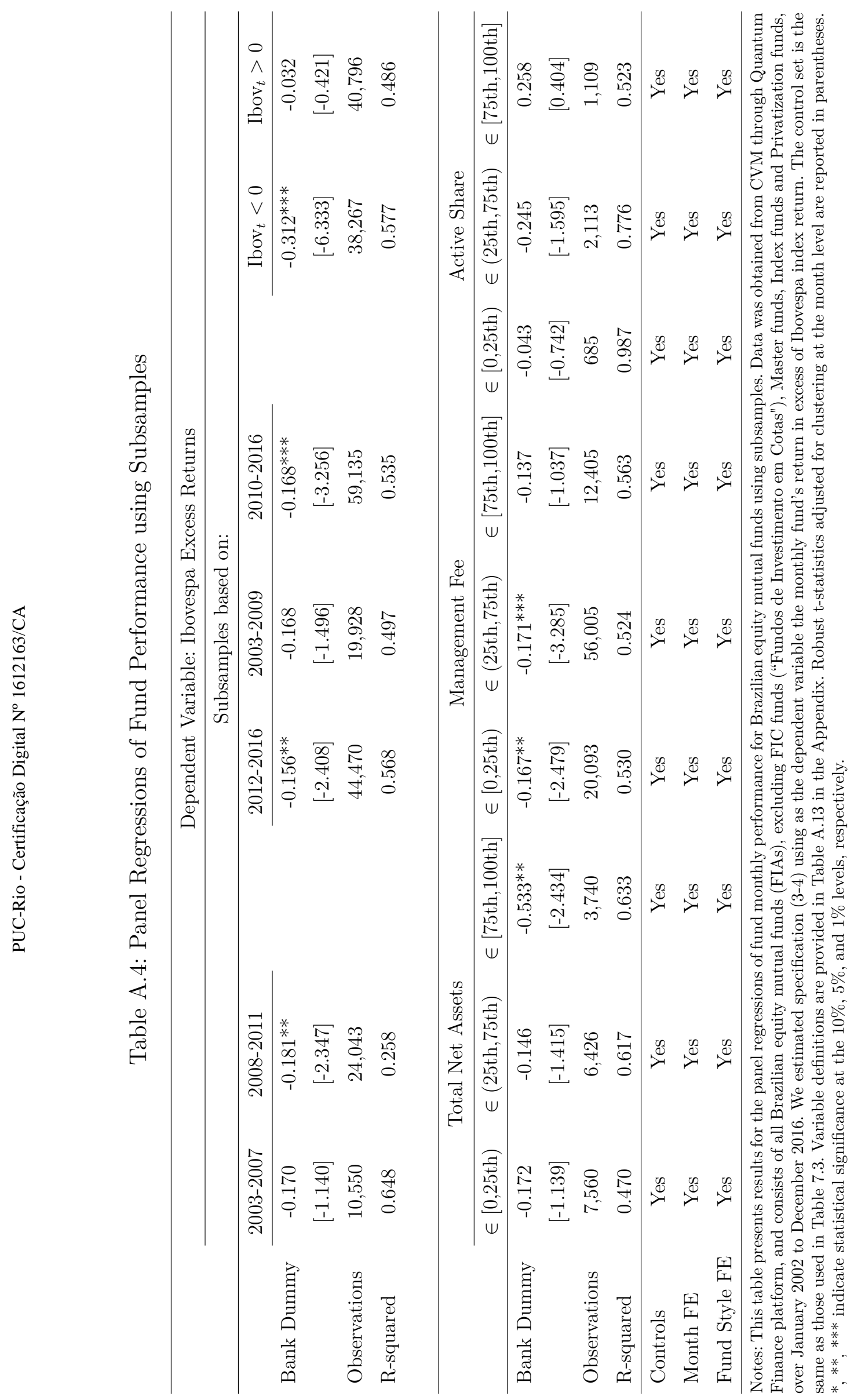


Table A.5: Heterogeneous Flow-Performance Relationship Using Quarterly Data

\begin{tabular}{lcccc}
\hline \multicolumn{5}{c}{ Percentile Rank Based on J-quarter Gross Return } \\
\hline & \multicolumn{4}{c}{ Flow $_{t}$} \\
\cline { 2 - 5 } & $\mathrm{J}=1$ & $\mathrm{~J}=2$ & $\mathrm{~J}=3$ & $\mathrm{~J}=4$ \\
\hline Low $_{t-1}$ & -0.084 & -0.053 & -0.043 & -0.067 \\
Mid $_{t-1}$ & {$[-1.451]$} & {$[-1.114]$} & {$[-0.845]$} & {$[-1.209]$} \\
& $0.062^{* * *}$ & $0.043^{* * *}$ & $0.038^{* * *}$ & $0.042^{* * *}$ \\
High $_{t-1}$ & {$[6.338]$} & {$[3.550]$} & {$[3.846]$} & {$[4.968]$} \\
& $0.096^{*}$ & $0.240^{* * *}$ & $0.252^{* * *}$ & $0.214^{* * *}$ \\
Bank $^{*}$ Low $_{t-1}$ & {$[1.958]$} & {$[3.840]$} & {$[5.363]$} & {$[5.974]$} \\
Bank $^{*}$ Mid $_{t-1}$ & $0.200^{* * *}$ & $0.144^{*}$ & $0.137^{*}$ & 0.080 \\
Bank $^{*}$ High $_{t-1}$ & {$[2.724]$} & {$[1.932]$} & {$[1.824]$} & {$[1.117]$} \\
& $-0.033^{*}$ & 0.001 & -0.001 & -0.004 \\
Bank dummy $_{t}$ & $0.210^{* *}$ & {$[0.079]$} & {$[-0.050]$} & {$[-0.255]$} \\
& $-0.038^{* * *}$ & $-0.033^{* * *}$ & -0.033 & -0.020 \\
& {$[-3.257]$} & {$[-2.813]$} & {$[-2.309]$} & {$[-1.431]$} \\
Observations & 29,137 & 29,133 & 27,949 & 26,765 \\
R-squared & 0.094 & 0.096 & 0.084 & 0.076 \\
Controls & Yes & Yes & Yes & Yes \\
Month FE & Yes & Yes & Yes & Yes \\
Fund Style FE & Yes & Yes & Yes & Yes \\
\hline
\end{tabular}

Notes: This table presents results for the panel regressions of quarterly flows on performance ranking and controls. Data was obtained from CVM through Quantum Finance platform, and consists of all Brazilian equity mutual funds (FIAs), excluding FIC funds ("Fundos de Investimento em Cotas"), Master funds, Index funds and Privatization funds, over January 2002 to December 2016. Each column represents Equation (4-4) using rankings based on 1, 2, 3 and 4-quarter accumulated gross return. All control variables are lagged by one period. Variable definitions are provided in Table A.13 in the Appendix. Robust t-statistics adjusted for clustering at the month level are reported in parentheses. *,**,*** indicate statistical significance at the $10 \%, 5 \%$, and $1 \%$ levels, respectively. 
Table A.6: Flow-Performance Relationship and Sensitivity Interaction With Other Variables

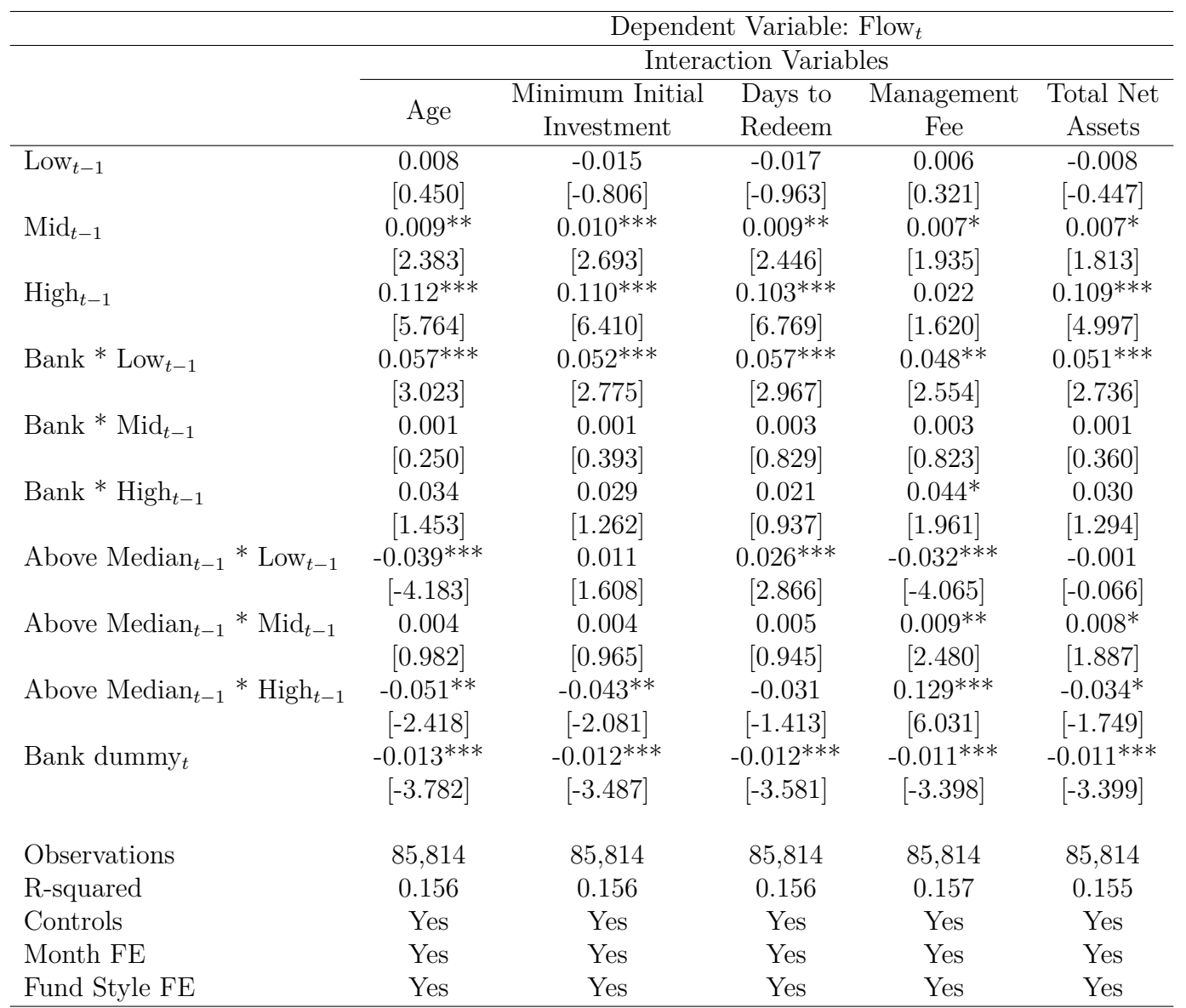

Notes: This table presents results for the panel regressions of monthly flows on performance ranking, controls and flowperformance interactions with dummy variables based on fund's features besides bank-affiliation. Data was obtained from CVM through Quantum Finance platform, and consists of all Brazilian equity mutual funds (FIAs), excluding FIC funds ("Fundos de Investimento em Cotas"), Master funds, Index funds and Privatization funds, over January 2002 to December 2016. Each column represents Equation (4-4) using rankings based 6-month accumulated gross return and the Above Median defined on the feature displayed above the column. Above Median is a dummy which is equal to 1 if the observation is above the median for certain feature and 0 otherwise. Variable definitions are provided in Table A.13 in the Appendix. Robust t-statistics adjusted for clustering at the month level are reported in parentheses. $*, * *, * * *$ indicate statistical significance at the $10 \%, 5 \%$, and $1 \%$ levels, respectively. 


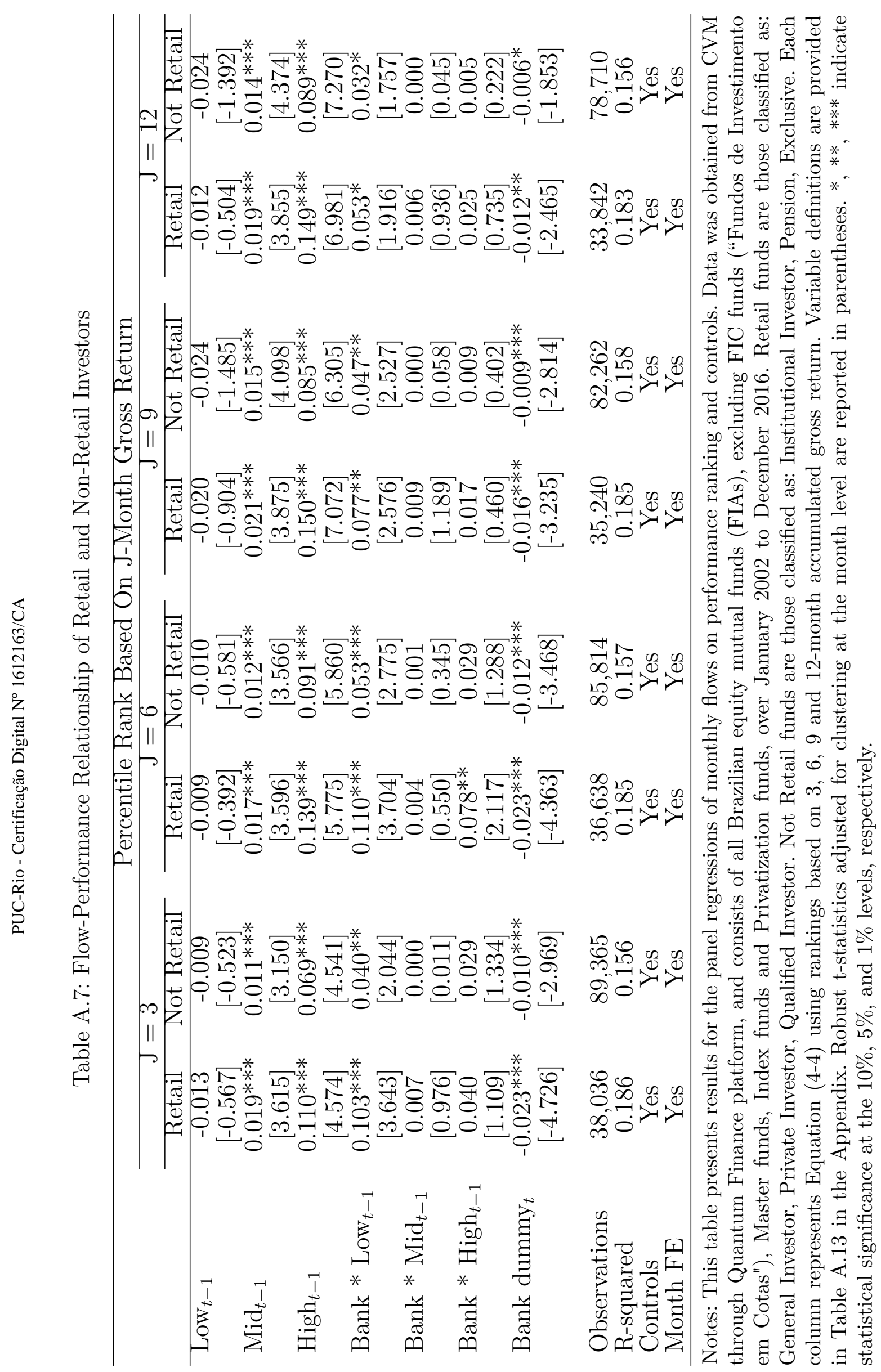


Table A.8: Conditional Differences in Risk Taking by Equity Mutual Funds

\begin{tabular}{|c|c|c|c|c|}
\hline \multicolumn{5}{|c|}{ Panel A - OLS Panel Regressions } \\
\hline & \multicolumn{4}{|c|}{ Dependent Variable } \\
\hline & Active Share & Turnover & Tracking Error $(\beta=1)$ & Tracking Error $(\hat{\beta})$ \\
\hline Bank Dummy & $-11.09^{* * *}$ & $-1.51^{*}$ & $-0.58^{* * *}$ & $-0.32^{* * *}$ \\
\hline & {$[-9.75]$} & {$[-1.93]$} & {$[-4.29]$} & {$[-2.61]$} \\
\hline Log TNA & -0.41 & $-1.07 * * *$ & $-0.15^{* * *}$ & $-0.18^{* * *}$ \\
\hline & {$[-1.35]$} & {$[-4.35]$} & {$[-3.50]$} & {$[-4.68]$} \\
\hline Log Family TNA & $-0.75^{* * *}$ & -0.25 & -0.02 & 0.00 \\
\hline & {$[-3.24]$} & {$[-1.03]$} & {$[-0.52]$} & {$[0.09]$} \\
\hline Age & $-0.54^{* * *}$ & 0.05 & -0.01 & -0.01 \\
\hline & {$[-5.98]$} & [0.90] & {$[-0.76]$} & {$[-0.61]$} \\
\hline Management Fee & $\begin{array}{c}0.06 \\
{[1.19]}\end{array}$ & $\begin{array}{c}0.04 \\
{[0.61]}\end{array}$ & $\begin{array}{l}-0.01 \\
{[-1.63]}\end{array}$ & $\begin{array}{c}0.01 \\
{[0.14]}\end{array}$ \\
\hline Flow & $\begin{array}{c}1.04 \\
{[1.27]}\end{array}$ & $\begin{array}{c}-4.57^{* * *} * \\
{[-3.76]}\end{array}$ & $\begin{array}{c}0.91 * * * \\
{[5.81]}\end{array}$ & $\begin{array}{c}0.79 * * * \\
{[5.05]}\end{array}$ \\
\hline Gross Return & $\begin{array}{c}0.04 \\
{[1.58]}\end{array}$ & $\begin{array}{c}-0.21^{* * *} \\
{[-4.72]}\end{array}$ & $\begin{array}{c}-0.05 * * * \\
{[-5.11]}\end{array}$ & $\begin{array}{c}-0.04^{* * *} \\
{[-4.81]}\end{array}$ \\
\hline Observations & 70,328 & 66,785 & 80,252 & 53,725 \\
\hline R-squared & 0.96 & 0.26 & 0.83 & 0.82 \\
\hline Time FE & Yes & Yes & Yes & Yes \\
\hline Style FE & Yes & Yes & Yes & Yes \\
\hline \multicolumn{5}{|c|}{ Panel B -Fama MacBeth Regressions } \\
\hline & \multicolumn{4}{|c|}{ Dependent Variable } \\
\hline & Active Share & Turnover & Tracking Error $(\beta=1)$ & Tracking Error $(\hat{\beta})$ \\
\hline Bank Dummy & $\begin{array}{c}-4.93^{* * *} \\
{[0.84]}\end{array}$ & $\begin{array}{c}-0.76^{* * *} \\
{[0.27]}\end{array}$ & $\begin{array}{c}-0.28^{* * *} \\
{[0.03]}\end{array}$ & $\begin{array}{c}-0.15^{* * *} \\
{[0.02]}\end{array}$ \\
\hline Observations & 70,328 & 66,785 & 80,252 & 53,725 \\
\hline Average R-squared & 0.28 & 0.16 & 0.13 & 0.18 \\
\hline Controls & Yes & Yes & Yes & Yes \\
\hline Number of periods & 145 & 142 & 169 & 146 \\
\hline
\end{tabular}

Notes: This table presents results for the panel regressions of fund monthly risk measures. Data was obtained from CVM through Quantum Finance platform, and consists of all Brazilian equity mutual funds (FIAs), excluding FIC funds ("Fundos de Investimento em Cotas"), Master funds, Index funds and Privatization funds, over January 2002 to December 2016. We run the following regression:

RiskMeasure $_{i, t}=\gamma$ Bank $+\beta_{1} \log$ TNA $_{i, t-1}+\beta_{2} \operatorname{LogFamilyTNA}_{i, t-1}+\beta_{3}$ Age $_{i, t-1}+\beta_{4}$ ManagementFee $_{i, t-1}+$ $\beta_{5}$ Flow $_{i, t-1}+\beta_{6}$ ExcessReturn $_{i, t-1}+\epsilon_{i, t}$

Panel A presents results from estimating the equation above using OLS. Panel B presents results from estimating the equation above using) (28) method. All the control variables are lagged by one month. Risk measures are defined in the Appendix. Variable definitions are provided in Table A.13 in the Appendix. Robust t-statistics are reported in parentheses. ${ }^{*},{ }^{* *},{ }^{* * *}$ indicate statistical significance at the $10 \%, 5 \%$, and $1 \%$ levels, respectively. 
Table A.9: Brazilian Equity Mutual Funds' Tournament Behavior

\begin{tabular}{lccc}
\hline & \multicolumn{3}{c}{$\Delta \overline{\text { Active Share }}_{i, t}$} \\
\hline Bank Dummy & 0.369 & 0.539 & 0.661 \\
& {$[1.004]$} & {$[1.373]$} & {$[1.546]$} \\
Rank $_{i, t-1}$ & 0.379 & 0.501 & 0.497 \\
Bank $_{i, t-1}{ }^{*}$ Rank $_{i, t-1}$ & {$[0.961]$} & {$[1.253]$} & {$[0.934]$} \\
& -0.630 & -0.765 & 0.092 \\
Rank $_{i, t-1}$ & {$[-0.981]$} & {$[-1.184]$} & {$[0.098]$} \\
& & & 0.126 \\
Bank $_{i, t-1}{ }^{*}$ Rank $_{i, t-1}^{F}$ & & & {$[0.314]$} \\
& & & -1.089 \\
Observations & & & {$[-1.401]$} \\
R-squared & 5,072 & 5,005 & 4,305 \\
Controls & 0.039 & 0.042 & 0.047 \\
Month FE & No & Yes & Yes \\
Fund Style FE & Yes & Yes & Yes \\
\hline
\end{tabular}

Notes: This table presents results for the panel regressions of semi-annual changes in fund's risk. Data was obtained from CVM through Quantum Finance platform, and consists of all Brazilian equity mutual funds (FIAs), excluding FIC funds ("Fundos de Investimento em Cotas"), Master funds, Index funds and Privatization funds, over January 2002 to December 2016. The regressions results are from Equation (5-1) using OLS. $\Delta \overline{\text { Active Share }}_{i, t}$ is the difference between the average active share of fund $i$ in the second semester and the first semester of year $t$.Active share is defined in the Appendix. Variable definitions are provided in Table A.13 in the Appendix ?? . Robust t-statistics are reported in parentheses. ${ }^{*}, * *, * * *$ indicate statistical significance at the $10 \%, 5 \%$, and $1 \%$ levels, respectively. 
Table A.10: Fund's Return Volatility and Active Share

\begin{tabular}{|c|c|c|c|c|c|}
\hline & \multicolumn{5}{|c|}{ Dependent Variable: Fund's Return Standard Deviation } \\
\hline & $\mathrm{h}=0$ & $\mathrm{~h}=3$ & $\mathrm{~h}=6$ & $\mathrm{~h}=9$ & $\mathrm{~h}=12$ \\
\hline \multirow[t]{2}{*}{ Mean Active Share ${ }_{t, t-h}$} & $0.250^{* * *}$ & $0.215^{* * *}$ & $0.152^{* * *}$ & $0.106^{* *}$ & 0.069 \\
\hline & {$[5.841]$} & {$[4.935]$} & {$[3.404]$} & {$[2.316]$} & {$[1.483]$} \\
\hline \multirow[t]{2}{*}{ Log TNA } & $-0.120 * * *$ & $-0.120 * * *$ & $-0.122^{* * *}$ & $-0.123^{* * *}$ & $-0.125 * * *$ \\
\hline & {$[-23.498]$} & {$[-23.235]$} & {$[-23.346]$} & {$[-23.437]$} & {$[-23.417]$} \\
\hline \multirow[t]{2}{*}{ Log Family TNA } & 0.004 & $0.006^{*}$ & $0.006^{*}$ & 0.006 & 0.004 \\
\hline & [1.184] & {$[1.757]$} & {$[1.796]$} & [1.599] & {$[1.221]$} \\
\hline \multirow[t]{2}{*}{ Log Age } & 0.002 & 0.002 & 0.002 & $0.002^{*}$ & $0.002^{*}$ \\
\hline & [1.563] & [1.295] & [1.434] & [1.666] & [1.792] \\
\hline \multirow[t]{2}{*}{ Management Fee } & $-0.393^{* * *}$ & $-0.381 * * *$ & $-0.370 * * *$ & $-0.364^{* * *}$ & $-0.353^{* * *}$ \\
\hline & {$[-3.863]$} & {$[-3.812]$} & {$[-3.794]$} & {$[-3.817]$} & {$[-3.878]$} \\
\hline \multirow[t]{2}{*}{ Flow } & $0.195^{* *}$ & $0.157^{*}$ & 0.126 & 0.153 & 0.128 \\
\hline & {$[2.113]$} & [1.679] & [1.321] & {$[1.556]$} & [1.315] \\
\hline Observations & 63,214 & 61,962 & 60,385 & 58,884 & 57,395 \\
\hline R-squared & 0.925 & 0.926 & 0.926 & 0.927 & 0.927 \\
\hline Month FE & Yes & Yes & Yes & Yes & Yes \\
\hline Style FE & Yes & Yes & Yes & Yes & Yes \\
\hline
\end{tabular}

Notes: This table presents results for the panel OLS regressions of fund's return volatility on lagged active share and controls:

$$
\sigma_{i, t}=\overline{\text { Active Share }}_{i, t, t-h}+\boldsymbol{\beta}^{\prime} \text { Controls }_{i, t-1}+\epsilon_{i, t-1}
$$

, where $\sigma_{i, t}$ is the fund i return standard deviation computed using the 12 previous months as data, $\overline{\text { Active Share }}_{i, t, t-h}$ is the fund $\mathrm{i}$ average Active Share during the previous $\mathrm{h}$ months (when $\mathrm{h}=0$, we use the lagged active share), and other controls are defined in Table A.1 in Appendix ??. Data was obtained from CVM through Quantum Finance platform, and consists of all Brazilian equity mutual funds (FIAs), excluding FIC funds ("Fundos de Investimento em Cotas"), Master funds, Index funds and Privatization funds, over January 2002 to December 2016. Robust t-statistics are reported in parentheses. *, **, *** indicate statistical significance at the $10 \%, 5 \%$, and $1 \%$ levels, respectively. 
Table A.11: Active Share and Risk-Adjusted Returns

\begin{tabular}{lccccc}
\hline & \multicolumn{5}{c}{ Dependent Variable: 4-factor Alpha ${ }_{t, t+h}(\%)$} \\
\cline { 2 - 7 } & $\mathrm{h}=0$ & $\mathrm{~h}=3$ & $\mathrm{~h}=6$ & $\mathrm{~h}=9$ & $\mathrm{~h}=12$ \\
\hline \multirow{3}{*}{ Bank Dummy } & & & & & \\
& $-0.223^{* * *}$ & $-0.423^{* * *}$ & $-1.031^{* * *}$ & $-1.691^{* * *}$ & $-2.423^{* * *}$ \\
4-factor Alpha & {$[-4.802]$} & {$[-5.555]$} & {$[-9.765]$} & {$[-16.505]$} & {$[-24.573]$} \\
& 0.006 & $1.009^{* * *}$ & $1.113^{* * *}$ & $1.154^{* * *}$ & $1.185^{* * *}$ \\
Log TNA & {$[0.120]$} & {$[15.697]$} & {$[13.974]$} & {$[11.992]$} & {$[10.691]$} \\
& $0.045^{* *}$ & $0.119^{* * *}$ & $0.355^{* * *}$ & $0.627^{* * *}$ & $0.866^{* * *}$ \\
Log Family TNA & {$[2.912]$} & {$[7.288]$} & {$[10.447]$} & {$[15.735]$} & {$[25.186]$} \\
& $0.040^{* * *}$ & $0.077^{* * *}$ & $0.188^{* * *}$ & $0.318^{* * *}$ & $0.459^{* * *}$ \\
Flow & {$[3.942]$} & {$[4.449]$} & {$[7.274]$} & {$[13.247]$} & {$[18.189]$} \\
& 0.628 & 0.147 & 2.370 & 3.295 & 3.915 \\
Age & {$[0.582]$} & {$[0.073]$} & {$[0.973]$} & {$[1.140]$} & {$[1.281]$} \\
& 0.000 & -0.002 & -0.005 & $-0.016^{*}$ & $-0.027^{* * *}$ \\
Management Fee & {$[0.085]$} & {$[-0.471]$} & {$[-0.604]$} & {$[-1.995]$} & {$[-5.643]$} \\
& $0.005^{* *}$ & $0.011^{* * *}$ & $0.033^{* * *}$ & $0.155^{* * *}$ & $0.261^{* * *}$ \\
Performance Fee & {$[2.301]$} & {$[4.083]$} & {$[4.412]$} & {$[5.747]$} & {$[11.167]$} \\
& 0.284 & 0.562 & $1.466^{* * *}$ & $2.535^{* * *}$ & $3.670^{* * *}$ \\
Active Share * $* 00$ & {$[1.085]$} & {$[1.315]$} & {$[3.121]$} & {$[4.876]$} & {$[9.344]$} \\
& 0.199 & 0.439 & $1.273^{* *}$ & $1.863^{* * *}$ & $2.285^{* * *}$ \\
& {$[0.571]$} & {$[0.869]$} & {$[2.337]$} & {$[3.262]$} & {$[5.208]$} \\
Observations & & & & & \\
R-squared & 52,407 & 51,440 & 48,606 & 45,890 & 43,284 \\
Month Fixed Effects & 0.469 & 0.561 & 0.493 & 0.489 & 0.504 \\
Classification Fixed Effects & Yes & Yes & Yes & Yes & Yes \\
\hline
\end{tabular}

Notes: This table presents results for the panel regressions of h-month fund's gross return in excess of Ibovespa on Active Share and other controls. Data was obtained from CVM through Quantum Finance platform, and consists of all Brazilian equity mutual funds (FIAs), excluding FIC funds ("Fundos de Investimento em Cotas"), Master funds, Index funds and Privatization funds, over January 2002 to December 2016. The dependent variable, the 4-factor Carhart alpha is measured in \%. All controls are lagged by one period. Risk measures are defined in the Appendix. Variable definitions are provided in Table A.13 in the Appendix. Robust t-statistics are reported in parentheses. *, **, *** indicate statistical significance at the $10 \%, 5 \%$, and $1 \%$ levels, respectively. 


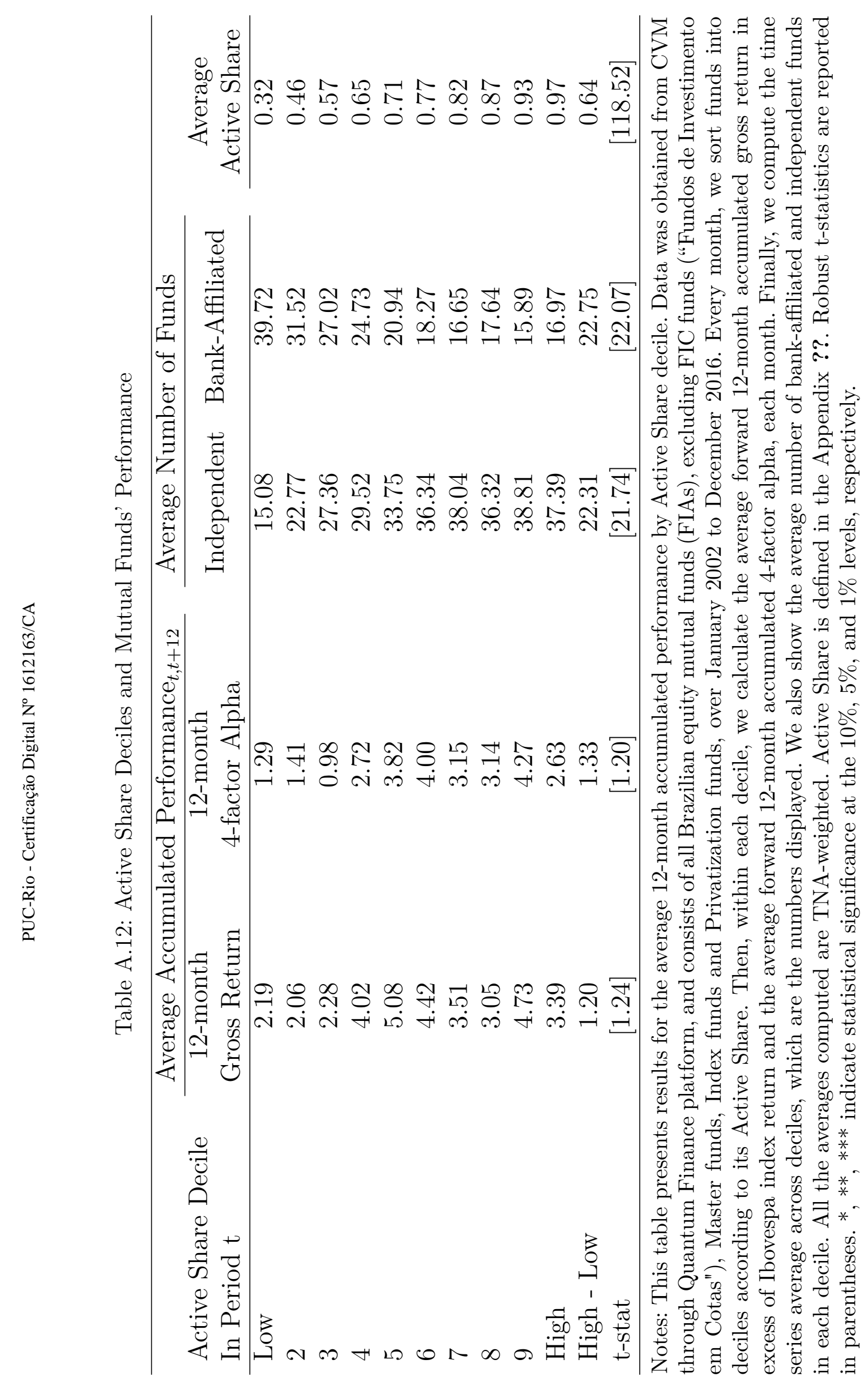




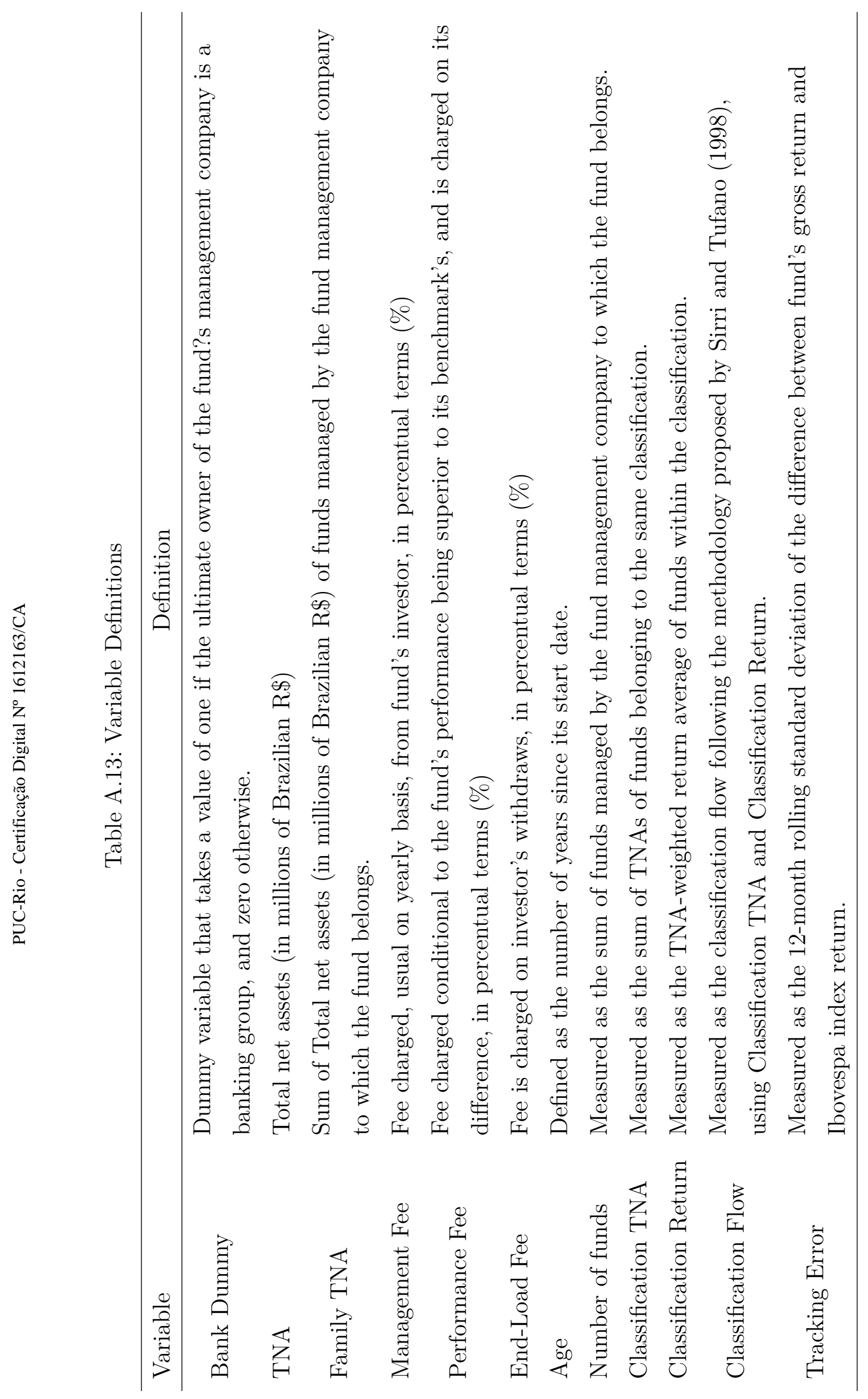

